\title{
B2B relationship calculus: quantifying resource effects in service-dominant logic
}

\author{
Anthony J. deLeon ${ }^{1} \cdot$ Sharmila C. Chatterjee ${ }^{2}$
}

Received: 10 September 2013 / Accepted: 4 November 2015 / Published online: 10 December 2015

(C) The Author(s) 2015. This article is published with open access at Springerlink.com

\begin{abstract}
Increasingly, knowledgeable business-to-business (B2B) customers and evolving customer needs are leading to seismic shifts in vendor-client interactions. Across industries, sellers are changing their business models from a simple goods orientation to a hybrid goods-services model, placing greater emphasis on delivering complete customer solutions. In such an environment, companies must find ways to prioritize investments in resource development. The servicedominant (S-D) logic framework offers significant insights into this challenge; however, these effects have not been tested quantitatively. This study addresses that gap, examining the influence of various seller resources on buyer satisfaction. An empirical analysis of buying organizations that purchased and implemented business intelligence systems finds that "augmented" operant resources that the buyers ascribe to the software's sellers - resources that go above and beyond expectations - are the most significant predictors of both successful technology assimilation and overall customer relationship quality. In particular, an augmented operant resource reflecting a seller's ability to see value creation opportunities from the buyer's perspective (value mindset) has up to three times the effect on relationship satisfaction as "core" operant resources such as product-specific expertise or basic interpersonal service skills. These results can help sellers prioritize resource investments.
\end{abstract}

Sharmila C. Chatterjee

schatterjee@mit.edu

Anthony J. deLeon

adeleon@ggu.edu

1 Golden Gate University, San Francisco, CA, USA

2 Management Science - Marketing, MIT Sloan School of Management, Cambridge, MA, USA
Keywords Business intelligence $\cdot$ Business-to-business marketing $\cdot$ Operand and operant resources $\cdot$ Relational performance $\cdot$ Realized value $\cdot$ Relationship satisfaction . Service-dominant logic $\cdot$ Technology assimilation $\cdot$ Value mindset

Given the rapid emergence of hybrid goods-services organizations across industries (Baines and Lightfoot 2013; Shankar et al. 2009; Ulaga and Reinartz 2011), traditionally goods-oriented companies face an increasingly important business development question: what services should they invest in? Or, put more analytically, what services have the greatest impact on customer relationships? The expanding service-dominant (S-D) logic literature (Vargo and Lusch 2004, 2008b) casts this question in terms of developing and applying "resources" to create value. According to S-D logic, value is not intrinsic to the seller's "operand resources" or tangible offerings such as physical products or software coupled with training or integration. Rather, sellers deliver value to buyers by applying operant resources such as skills and knowledge to the operand resources.

Vargo and Lusch (2008a) maintain that the valuemaximizing application of resources - more than the specific goods-services offering mix - should be a company's primary marketing concern. To date, though, little quantitative analysis has been conducted to test the impact of these resources on value. Research has focused instead on classification systems (Madhavaram and Hunt 2008), consumer behavior (Arnould 2005), and conceptual integration into existing knowledge domains such as innovation theory (Michel et al. 2008). Recent qualitative studies have highlighted the importance of sellers customizing offerings and communicating value in customer-specific terms (Tuli et al. 2007; Ulaga and Reinartz 2011). But, again, the impact of such capabilities has yet to be assessed through quantitative analysis. 
Given the paradigmatic shift proposed by S-D logic, the first objective of our study is to quantitatively assess the extent to which both operant and operand resources affect value. We measure value in terms of project outcomes and customer relationship satisfaction. To do this we quantify relative effects both within operant resources, and between operant and operand resources, while simultaneously capturing co-creation of value.

Buyers and sellers may also have very different notions of success. This is shown vividly by Tuli et al. (2007), who find suppliers viewing customer solutions from a goods/services perspective in contrast to customers viewing solutions from a relational perspective. The empirical work that does exist establishing the value of operant resources on value creation has been seller- rather than buyer-centered, and it has not included relative quantitative assessments for specific resources (Ngo and O'Cass 2009). Our second objective then is to illuminate the buyer's perspective, analyzing the impact of a seller's operant and operand resources on customer perceptions of value created. We do this using a holistic, end-to-end framework, which allows us to measure the relative contribution of distinctive seller resources (as perceived by the buyer) while concurrently depicting value co-creation.

Our setting is the business-to-business (B2B) software industry, specifically business intelligence (BI) systems, a class of enterprise software. It is an instructive environment given that many B2B and technology companies already augment products with services to develop more complete customer solutions (Helander and Moller 2008; Kauffman and Tsai 2009). In particular, services including installation support, project management, and user training-whether delivered through a software group's internal resources or via third parties - help customers tackle a key challenge: moving from initial adoption of a product to enterprise-wide use and benefits realization (Samli et al. 1992; Easingwood et al. 2006; Swaminathan and Moorman 2009). This type of solution selling strongly supports the S-D logic principle of "value in use," where value is co-created by the buyer through product use (Devaraj and Kohli 2003) and by the seller through the contribution of operant resources applied in conjunction with the product (Ngo and O'Cass 2009).

The software industry also provides a relevant setting because IT implementation projects are notoriously unpredictable and subject to frequent failure (Keil and Mähring 2010). Yet Global IT expenditures continue to grow, exceeding \$3.75 trillion in 2014 (Gordon and Lovelock 2014). With services and support costs significantly outweighing the software product cost component (typically less than $10 \%$ of the total cost of ownership; MacCormack 2003), software companies that can leverage services investments into better project outcomes for customers - and, ultimately, greater customer satisfaction and business performance - will boast a significant competitive advantage (Rust and Oliver 2000).
This study makes important contributions to both academia and industry. While prior research established a conceptual foundation and qualitative support for strengthening operant resources, this study constitutes, to the best of our knowledge, the first empirical evaluation of their relative effects and the first exploration of principles for prioritizing them. We look at three types of seller operant resources, categorizing them as either "core" or "augmented." Core resources fulfill basic customer expectations. Augmented resources go beyond basic expectations and enhance seller differentiation. Instrumental service is a core resource reflecting the seller's product-specific expertise; interpersonal service is a core resource reflecting the seller's basic service-delivery skills; and value mindset is an augmented resource reflecting the seller's holistic understanding of the buyer's business context, value-realization opportunities, and implementation pathway to value.

Among the most striking results of our analysis was the degree to which value mindset improves a customer's perception of realized value and relationship quality. Its impact on a buyer's satisfaction with a relationship was three times that of either instrumental service or interpersonal service. These results appear to support the growing practice of software companies to augment their business models with services. The results also reveal that different facets of the services resource domain have different associations with customer-specific outcomes. The actual scope of services provided, an augmented operand resource, seems to have little influence on either a customer's success in assimilating technology or the customer's judgments about relationship quality. In contrast, the buyer-specific value mindset that a seller brings to a customer relationship has a strong positive influence on both technology assimilation and relationship satisfaction. This study thus provides strong empirical support for the basic premise of S-D logic: the critical importance of operant resources.

The second contribution of this study is to provide timely guidance for companies deciding where to invest for maximum impact, while taking the buyer's perspective. Our results demonstrate the value of investing in "soft" service facets versus more tangible, "hard" service facets. They also showcase the potential for high returns from human capital investments that facilitate a holistic customer value mindset. These investments can enhance relationship satisfaction, bring more positive word-of-mouth, and promote repurchase intent.

\section{Conceptual framework}

\section{Relational performance and its direct drivers}

Ramani and Kumar (2008) highlight "customer-based relational performance" as a concept reflecting (1) a customer's relational satisfaction with a particular seller, (2) the degree to which the customer feels "ownership" or accountability for 
the seller's financial performance, and (3) the customer's willingness to offer positive word-of-mouth in praise of the seller. Given the wealth of prior research (Bolton et al. 2003; Lam et al. 2004) linking high levels of relationship satisfaction with other favorable attitudes and behaviors (in particular, positive repurchase intent and word-of-mouth), we chose in this study to focus on relationship satisfaction as a pivotal measure that sellers can influence with their operant and operand resources.

The B2B relationship marketing literature identifies numerous factors encompassing both operant and operand resources that directly influence relationship satisfaction. Prominent drivers include instrumental factors established by the seller's marketing mix decisions (Abdul-Muhmin 2005), relational norms (Heide and John 1992), customer value (Ulaga and Eggert 2006a), customer orientation (Homburg 1998), key account management capabilities (Sengupta et al. 2000), and service augmentation strategies (Homburg et al. 2002). Drawing on Levitt's (1980) notion of the "total product," we can divide the seller's offering attributes (operand resources) into two categories: core operand resources, which fulfill basic customer expectations about a product (e.g., compliance with functional and technical requirements), and augmented operand resources, which help the seller to exceed customer expectations (e.g., installation, training, and support services). Operant resources also can be categorized along these lines: those addressing core expectations, and those related to augmented offerings.

Core operant resources A buyer's purchase expectations and the associated seller's service resources may be conceptualized in two broad categories: instrumental aspects addressing the performance or technical dimensions of the buyer-seller interaction, and interpersonal factors addressing the functional or process-related aspects of those interactions (AbdulMuhmin 2005; Gronroos 1984). Instrumental service is a core operant resource reflecting the degree of technical mastery exhibited by the seller's staff with respect to the core offering. Interpersonal service, on the other hand, is a core operant resource underlying service behaviors reflecting close attention to customer needs. In the context of software consulting services, instrumental service would encompass the product or domain-specific expertise provided by the seller's technical service staff. Interpersonal service would reflect the staff's more general service characteristics such as empathy, reliability, and responsiveness (Parasuraman et al. 1988).

Instrumental and interpersonal service factors are core operant resources in that they serve to establish basic customer expectation levels (Bruhn and Frommeyer 2004; Lai et al. 2013). These service components are the minimum expected by buyers in today's hypercompetitive sales environment, with lengthening sales cycles, increasing numbers of individuals involved on both sides of the dyad, and decreasing prospect conversion rates and margins (Adamson et al. 2013;
Evans et al. 2012). Instrumental and interpersonal service resources are more congruent with the traditional view of service on the part of many sellers.

Augmented operant resources Our concept of value mindset is built on the notion of Anderson and Narus (1998) "customer value models," which reflect sellers' efforts to articulate an offering's value in customer-relevant consumption terms. Value mindset is an augmented operant resource that encompasses the seller's grasp of the buyer's business context, how the product can enhance the buyer's performance within that context, and how the buyer can implement the product to realize maximum value (Abratt and Kelly 2002; Dawar and Vandenbosch 2004).

Value mindset is a refinement of the broader, more general concept of "customer orientation." Customer orientation implies an understanding of the buyer's value chain and competitive context (Slater and Narver 1994) but not necessarily how the buyer's organization might be changed to achieve greater value. In contrast, value mindset suggests not only that sellers understand the full, enterprise-wide value creation opportunity their offering provides in the buyer's unique context, but also the associated business changes needed on the part of the buyer to realize the value potential. This is a critical distinction since value extraction often requires strategy, structure, process or cultural change (Adamson et al. 2012). To this end, value mindset involves sharing with customers best business practices and lessons learned from failures at other organizations, to provide them with critical insights for value realization in their specific business context. Active customer involvement is therefore important for success. Increasingly, this sort of broader, more forward-looking seller mindset is demanded by empowered buyers who require "insight selling" as compared with the traditional sales model (Adamson et al. 2013).

In terms of S-D logic (Vargo and Lusch 2004), sellers are not simply transferring the value inherent in their offering, but are also promoting the "value-in-use" or consumption-derived value that matters to customers. Such a use-centered value mindset, in contrast with product-centered value perspectives (instrumental service), represents an S-D logic-based augmentation of the core offering.

Resource portfolio We may break down a seller's resources into core and augmented categories as illustrated in Fig. 1.

Assuming that a market-competitive core product is in place which fulfills the customer's functional and technical requirements, sellers seeking to strengthen their overall operand and operant resources have three broad options. First, they could expand their operand resources of tangible customer offerings by adding services (services scope) to augment the core product. Examples might include expansion of systems installation, integration or training 
Fig. 1 Vendor resources

\section{Core}

Augmented

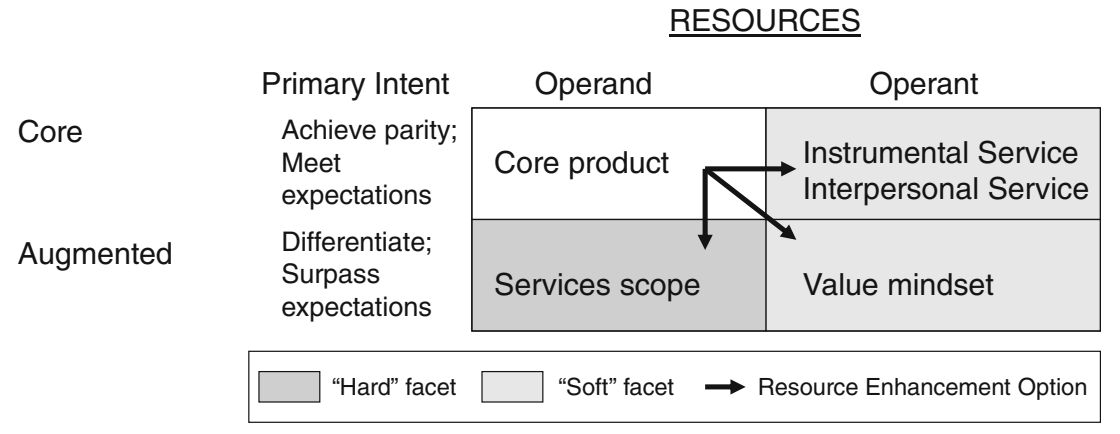

\section{Indirect drivers of relational performance}

services. Second, they could invest in operant resource development around the core product, focusing on either knowledge of the technical product or domain (instrumental service) or general service-delivery skills (interpersonal service). Examples here include internally focused staff technical training or service improvement initiatives. Third, they could invest in operant resources related less directly to the core product, and more to the customer's value-creating use of the product (value mindset). This could be facilitated by formation of user groups or buyer councils, or use of external hires or firm acquisitions to deepen the seller's vertical market expertise. We label the first enhancement option "hard" because it necessitates investments in the tangible offering, while the latter two are "soft" in that they require investments in human capital.

Our study We seek to understand the relative importance that firms should assign to their resource options. Thus, our analytical concern is two-fold. First, we need to understand the effect of different services on relationship satisfaction. As Vargo and Lusch (2004) suggest, it is primarily the operant resources that produce effects or outcomes - assuming a competitive product created from operand resources is being offered. Thus a model combining - but evaluating individually - the effects of core operant resources, such as instrumental service and interpersonal service, and augmented operant resources, such as value mindset, should offer useful insights into the seller resources that influence relationship satisfaction.

Second, for hybrid goods-services companies formulating a service-oriented strategy, we need to distinguish the effect of tangible, hard factors such as services scope, from that of soft factors such as the seller's mindset (Homburg et al. 2003). Consequently, as illustrated in Fig. 1, for a given customer utilizing a given core product deemed to have met the business's requirements, the key research questions center on the relative impact on realized value and relationship satisfaction of (1) core versus augmented seller operant resources and (2) the seller's augmented operant versus operand resources.
However, if value is truly co-created by both the seller and the buyer, then the buyer's ability to assimilate new technologywith support from the seller-will also affect perceived value and relationship satisfaction. We therefore model key elements of the buyer's technology assimilation process (Fichman 2000; Meyer and Goes 1988) in order to gauge indirect effects on realized value and relationship satisfaction. These technology assimilation elements (detailed in Appendix 2) are illustrated in Fig. 2, with relevant seller operant and operand resources as antecedents, and relationship satisfaction as a consequence.

Seller resources include core operant resources (instrumental service and interpersonal service), the augmented operant resource (value mindset), and the augmented operand resource (services scope). These resources are posited to affect relationship satisfaction directly, and also indirectly through assimilation constructs. In particular, these resources influence potential value, which gauges the buyer's sense of the "promise" of the technology (Davern and Kauffman 2000), and user enablement, which captures the buyer's inclination to facilitate widespread adoption of the technology within the organization (Mathieson et al. 2001). Potential value and value mindset differ in that the former can be independent of any particular buyer--seller relationship, while the latter pertains to the context of a specific buyer.

With this framework, we may characterize the direct effects of seller resources as reflecting the seller's traditional role as vendor, while the indirect effects (working through assimilation) reflect co-creation of value by both the buyer and seller.

\section{Relative effects of seller resources}

The relationship marketing and technology management literatures suggest that seller resources influence relationship satisfaction through both direct and indirect means. These associations constitute a complex system when viewed holistically, as in Fig. 3. Appendix 1 details operational definitions, measurement items, and supporting literature for each construct. 
Fig. 2 Overall conceptual model

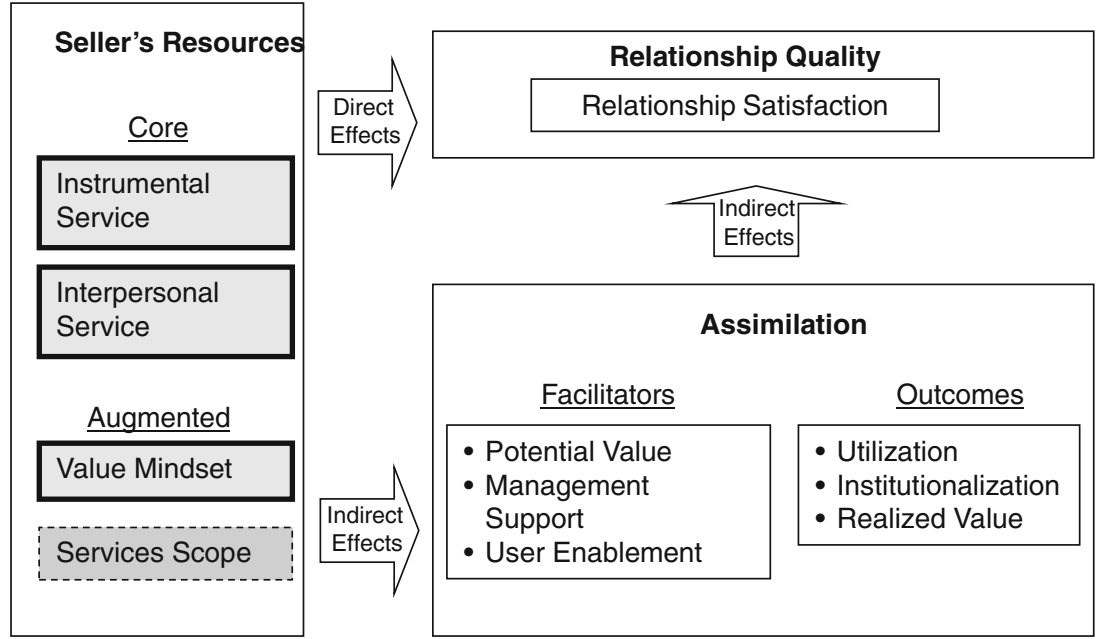

Operant Resource

Operand Resource

Because our central question concerns the relative value impact of operant and operand resources proposed in S-D logic, and how to prioritize seller resources, we quantify the aggregated direct and indirect effects of these resources on customer value. To reach the final sums, we added up the different paths. We tested the individual construct relationships (Path Hypotheses H1-H9) as a step toward identifying significant pathways between seller resources and elements of customer value. Since these path hypotheses are not our focus, we have shifted this discussion to Appendix 2.

Instead, we aim to test hypotheses combining direct and indirect effects about the relative effect of seller operant and operand resources on customer value, both economic (realized value) and relational (relationship satisfaction) (system hypotheses, or $\mathrm{SH}$ ). Based on a review of relevant literature, we expect that "soft" facets will trump "hard" facets. This argument is developed next. To date, there has been limited research looking at such relative effects; however, many studies - from across diverse geographic and industry settings - emphasize the importance of soft or interpersonal attributes over hard product-centric qualities (Kumar 2002; Lapierre 2000; Menon et al. 2005; Ulaga and Eggert 2006b). A theme in this literature is the importance of thinking beyond the core product toward a customer-centered view of the value-creation opportunity. Characteristics such as empathy, solidarity, and market knowledge are particularly valued by customers and tend to be associated with higher levels of relationship satisfaction.

Research looking at the impact of services expansion yields similar insights. Goods-centered firms looking to expand their services portfolio often seek to deliver more complete

Fig. 3 Research model

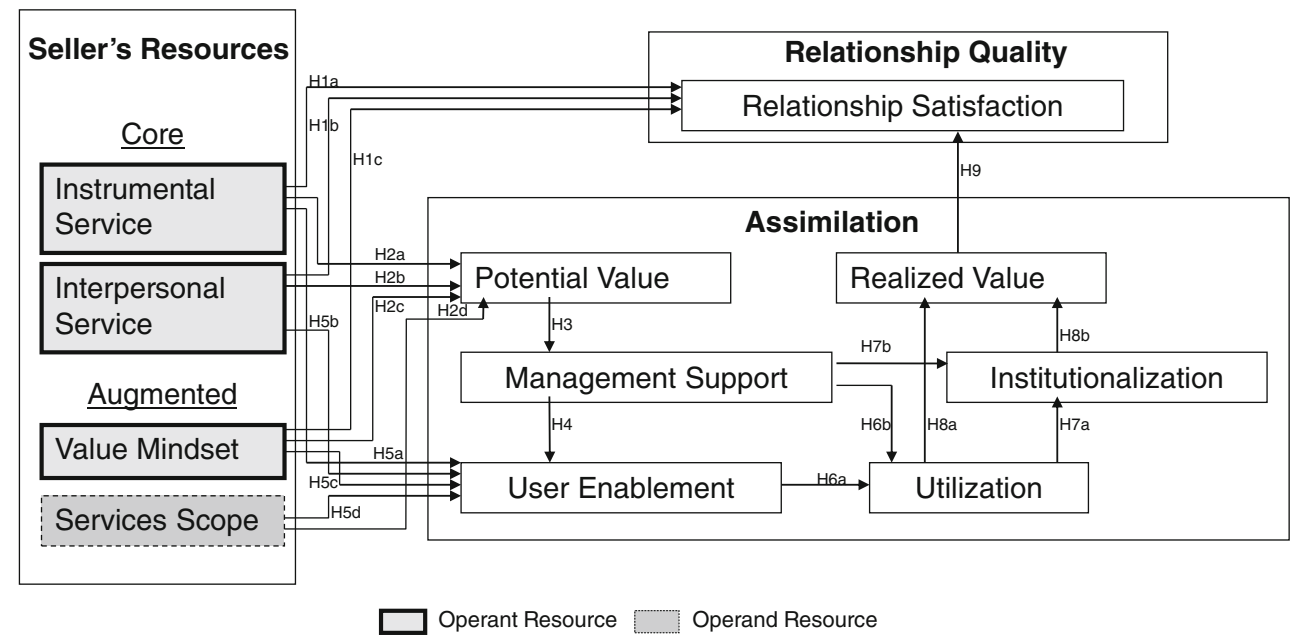


"solutions" to their customers, but encounter mixed results (Fang et al. 2008; Young 2008). Various case studies and other qualitative research highlight the need for organizational change to facilitate success with services strategies. Such changes include an evolution in the selling perspective from departmental to enterprise-wide solutions (Baines and Lightfoot 2013; Kauffman and Tsai 2009), development of "relational processes" that enable a customization of products and services to deliver customer value (Tuli et al. 2007), greater attention to synchronization in the seller's value-creating activities (Helander and Moller 2008), and a general organizational shift to a more customer-focused value and outcome orientation (Gebauer and Friedli 2005; Sawhney et al. 2004). Again, the recurring theme is the importance of the seller's development and communication of a customer consumption-specific value proposition (value-inuse) associated with the core products and services.

Given the importance of customer-centered soft factors in value determinations, we propose the following system hypotheses:

SH1a: A seller's value mindset will exhibit a greater impact than instrumental service (aggregated across significant assimilation paths) on the customer's realized value.

SH1b: A seller's value mindset will exhibit a greater impact than interpersonal service (aggregated across significant assimilation paths) on the customer's realized value.

For our purposes, realized value represents the buyer's assessment of the overall economic value resulting from the acquisition and implementation of the seller's offering along with any associated business changes. We also want to examine the relative impact of operant resources on relationship satisfaction. In the B2B context, relationship satisfaction is an aggregation of satisfaction judgments formed across multiple interactions and commercial exchanges between the buyer and seller (Anderson 1995). Buyer satisfaction judgments may arise from both direct assessments of seller representatives (Pardo 1997; Walter et al. 2003) and indirect assessments of the value realized from the commercial exchange (Eggert and Ulaga 2002; Lam et al. 2004). Therefore, seller resources should have both direct and indirect effects on relationship satisfaction. Resources affecting realized value (indirectly through assimilation) should have a comparable relative effect on relationship satisfaction. Thus, we propose that:

SH2a: A seller's value mindset will exhibit a greater total impact (direct plus indirect through assimilation) than instrumental service on relationship satisfaction.

SH2b: A seller's value mindset will exhibit a greater total impact (direct plus indirect through assimilation) than interpersonal service on relationship satisfaction.
Finally, in keeping with S-D logic principles (Vargo and Lusch 2008a), which stress the importance of operant versus operand resources in supporting value-in-use, it should be expected that the seller's augmented operant resources (value mindset) will have a greater impact on the customer's value and satisfaction judgments than the seller's augmented operand resources (services scope). Accordingly, we propose that:

SH3a: A seller's value mindset will exhibit a greater cumulative impact (aggregated across significant assimilation paths) than services scope on realized value.

SH3b: A seller's value mindset will exhibit a greater cumulative impact (direct plus indirect through assimilation) than services scope on relationship satisfaction.

\section{Research design}

The study methodology was a two-phase mixed method approach following the sequential exploratory design process outlined by Creswell (2003). Phase I involved exploratory interviews with knowledgeable informants involved in different aspects of the sale, installation, and ongoing use of business intelligence (BI) systems. Interviews were conducted with BI consulting companies such as Accenture and the Kimball Group, BI system sellers such as Cognos and Hyperion, and BI system buyers such as eBay and Visa. A more complete report on the Phase I interview findings is available from the authors upon request.

Interviews served to validate and refine the conceptual model and survey instrument. These interviews confirmed the potential for seller resources to positively influence BI customer success. The interviews also underscored the importance of augmenting core product resources with a broader view of how BI solutions create value in the customer context. To test the conceptual model and hypotheses, we next conducted a mail survey of organizations that had purchased and implemented BI solutions.

\section{Sample overview and data}

The two-wave survey targeted U.S. organizations from diverse industries. The sample frame consisted of 1975 organizations ranging in size from $\$ 1$ million to more than $\$ 1$ billion in annual sales. The primary source of prospective respondent contact information was Jigsaw Data, an internet-based directory of business executives which was later acquired by Salesforce.com, which currently offers the service as part of its Data.com offering. Two senior executive (C-level or VP) respondents from each organization were asked to provide their ex post assessments of the BI system implemented for the organization. A total of 429 of the targeted organizations 
had a specific executive identified with responsibility for BI initiatives.

Perceptual data were collected on vendor support and services, organization level variables, and BI system outcomes. The BI system had to be operational for at least 6 months to give respondents time to gauge the value created by the BI systems and services. The antecedents in this study are service-related and thus can be reliably measured after service experience (Gronroos 1990), thus supporting our crosssectional research design.

\section{Response rate and non-response bias}

Combining both waves, 157 responses from 123 organizations were received, representing a $6.2 \%$ overall response rate. We suspect that several of the organizations contacted in the initial wave may have failed to meet the criteria for inclusion in the study, either because they had no formal BI system in place or because their BI system was not yet operational for the 6-month minimum period. This would account in part for the low response rate. A higher response rate (11.9\%) was realized from the sub-group of respondents that had a specific BI executive (51 of 429 organizations).

There was little demographic difference between responders and non-responders. Cross-tabulations of the two groups revealed no significant differences by number of employees or industry class. There were some significant differences in response rates by revenue size, with both very small $(\angle \$ 10 \mathrm{M}$ in sales) and very large ( $>\$ 500 \mathrm{M}$ in sales) organizations exhibiting a slightly higher tendency to respond. However, one-way ANOVA tests of the major independent and dependent constructs showed no significant differences in the indicator values across any of the demographic factors. Given the representative nature of the sample, there is no a priori reason to believe the seller appraisals and BI experiences of the nonresponders would have varied significantly from those of the responders. Therefore, non-response bias, though always possible, is not likely to be a concern with our data.

\section{Common method bias}

In the context of organizational survey research, the use of multiple respondents is often suggested as a means to control for common method bias and to enhance the validity of the organization-level conclusions (Podsakoff and Organ 1986). However, some question the general significance of common method bias effects (Spector 2006), and in particular, the magnitude of their influence in discrete domains, such as IT system evaluations (Malhotra et al. 2006).

For this study, we believed that obtaining multiple organizational respondents was desirable but not essential. Multiple responses from the same organization were solicited, and aggregated based on weights determined by the degree of confidence expressed by each respondent for each section of the survey (Van Bruggen et al. 2002). We also tested the survey responses ex post for evidence of common method bias. Following the procedure recommended by Liang et al. (2007), we created an artificial "methods" construct as a predictor of each study variable. The results indicate that loadings for the various study indicators on the methods construct are much smaller than their loadings on the substantive, theoretical latent construct for each indicator and are not significant. Moreover, the overall percentage of variance in each indicator attributable to the methods construct was small ( 0.007 on average) as compared with the variance attributable to the substantive construct (0.896). Therefore, we conclude that common methods bias is not likely to be a concern for our data.

\section{Data analysis approach}

The variance-based Structural Equation Modeling (SEM) technique partial least squares (PLS) was used to analyze the survey responses. While covariance-based SEM is frequently used in marketing and information systems research, these covariance-based SEM techniques have proven problematic in situations - like that of this study - where theory is emergent (Chin 1998a; Chin and Todd 1995), where the research model includes both formative and reflective variables, and where the sample size is relatively small (Chin 1998b). Given the exploratory objectives of the study (quantifying the relative value impact of operant versus operand resources proposed in S-D logic, and prioritizing capability enhancement options rather than simply confirming the well-researched path relationships used to construct the research model), variance-based PLS offers a distinct advantage over covariance-based SEM (Hair et al. 2012). Moreover, PLS has been used in a wide range of studies of organizational technology adoption (e.g., Fichman and Kemerer 1997; Son and Benbasat 2007) in which the model characteristics did not lend themselves to covariance-based SEM approaches. PLS is emerging as a valuable analytical approach in marketing studies, as well (Hair et al. 2011). This study contributes yet another example of the PLS technique's usefulness in analyzing organizational technology adoption and marketing capability.

\section{Results}

Analysis of the dataset consisted of two main steps: (1) refinement of the PLS measurement model that defines the relationship between the observed variable indicators and the unobserved latent constructs, and (2) assessment of the structural model, represented by path coefficients between the latent constructs. Given the non-parametric assumptions underlying PLS, jackknifing or bootstrapping are used to assess standard errors and the stability of parameter estimates (Chin 1998b). 
Since jackknifing is less efficient, we assessed the statistical significance of parameter estimates based on bootstrapping with 500 re-samples.

\section{Measurement model refinement}

Construct definitions and measurement items are listed in Appendix 1. As a first step in scale validation, the indicators and constructs were evaluated and refined to ensure reliability (internal consistency) and convergent and discriminant validity. The resulting measurement model (Appendix 3) exhibits reliable indictors (Cronbach alpha's range from 0.79 to 0.96 for all the reflective variables), high-factor loadings ( 0.73 to 0.97), and high AVEs (0.69 to 0.90) indicative of convergent validity. We analyzed the AVEs and the inter-construct correlations (Chin 1998b; Fornell and Larcker 1981) and found the square roots of the AVEs for each construct exceeded the inter-construct correlations (Table 1).

Further, the cross loadings of indicators on all the constructs exhibited higher loadings on the assigned construct than on other constructs. Therefore, the refined measurement model demonstrates good discriminant validity.

PLS models are evaluated based on their predictive power, which is evident in the coefficient of determination $\left(\mathrm{R}^{2}\right)$ and Stone-Geisser test criteria $\left(\mathrm{Q}^{2}\right)$ for each endogenous construct (Chin 1998b). In this case, the results support the model's predictive relevance since the $\mathrm{R}^{2}$ values for the endogenous constructs all exceed 0.3 (Herrmann et al. 2007). Also, the Stone-Geisser criteria are greater than zero for each construct.

\section{Structural model assessment}

The next major analytical step was to use PLS to compute path coefficients among the latent constructs with a separate bootstrap procedure (based on 500 re-samples of the underlying data) performed to calculate $t$-values for significance testing. Following the approach used in comparable PLS studies (e.g., Liang et al. 2007; Srite and Karahanna 2006), control variables were tested along with the theoretical variables as predictors in a "full" model. Non-significant control variables were then dropped from the "final" model, which served as the basis for hypothesis testing. Buyer size and system operational duration proved non-significant as predictors of institutionalization, and were dropped. As suggested by the technology acceptance model literature, perceived usefulness and perceived ease of use were significant predictors of utilization, and were retained in the final model. Similarly, third party services was a significant predictor of potential value (though not of user enablement) and was also retained. The path coefficient results aligned with the various hypotheses are illustrated in Fig. 4.

\section{Effect size of operant versus operand resources}

Viewed as individual construct relationships, the hypotheses test results tend to confirm relationships established in the literature. Viewed as a holistic model, the results are much more striking. We find that sellers with a strong "soft" service capability (value mindset) have the greatest impact on realized value and relationship satisfaction.

In general, seller resources have differential effects on the assimilation facilitators. In particular, the effect on potential value $\left(\beta_{\mathrm{INST} \rightarrow \mathrm{PV}}=0.38, \beta_{\mathrm{VM} \rightarrow \mathrm{PV}}=0.3\right)$ appears to be stronger than on user enablement $\left(\beta_{\mathrm{INTP} \rightarrow \mathrm{UE}}=0.22, \beta_{\mathrm{VM} \rightarrow \mathrm{UE}}=0.22\right.$, $\beta_{\mathrm{SS} \rightarrow \mathrm{UE}}=0.16$ ), suggesting that executive perceptions of potential value regarding the $\mathrm{B} 2 \mathrm{~B}$ technology are a more accessible leverage point for sellers than enterprise-wide usage facilitation. In terms of augmented versus core resources, the

Table 1 Latent variable correlations (Kandall's Tau)

\begin{tabular}{|c|c|c|c|c|c|c|c|c|c|c|c|}
\hline Constructs & Items & 1 & 2 & 3 & 4 & 5 & 6 & 7 & 8 & 9 & 10 \\
\hline 1. Interpersonal service & 5 & 0.883 & & & & & & & & & \\
\hline 2. Instrumental service & 4 & 0.348 & 0.832 & & & & & & & & \\
\hline 3. Value mindset & 4 & 0.311 & 0.389 & 0.943 & & & & & & & \\
\hline 4. Relationship satisfaction & 4 & 0.484 & 0.423 & 0.628 & 0.949 & & & & & & \\
\hline 5. Potential value & 5 & $0.178 *$ & 0.256 & 0.336 & 0.302 & 0.869 & & & & & \\
\hline 6. Management support & 3 & 0.225 & 0.242 & 0.295 & 0.304 & 0.520 & 0.950 & & & & \\
\hline 7. User Enablement & 4 & 0.360 & 0.295 & 0.423 & 0.430 & 0.375 & 0.421 & 0.893 & & & \\
\hline 8. Utilization & 2 & $0.035^{\mathrm{ns}}$ & $0.197 *$ & 0.276 & 0.264 & 0.342 & 0.309 & 0.282 & 0.947 & & \\
\hline 9. Institutionalization & 2 & $0.168^{*}$ & 0.275 & 0.523 & 0.453 & 0.414 & 0.334 & 0.400 & 0.304 & 0.910 & \\
\hline 10. Realized value & 6 & 0.237 & 0.278 & 0.501 & 0.476 & 0.440 & 0.377 & 0.436 & 0.407 & 0.587 & 0.902 \\
\hline
\end{tabular}

All correlations are significant at $p<.001$ level (2-sided test) except as indicated: $* p<.01$, ${ }^{\text {ns }}$ non-significant

Diagonal elements are the square root of the average variance explained (AVE) for each latent variable

Discriminant validity is established when the square root of AVE exceeds the construct intercorrelations, as reflected in the off-diagonal elements 


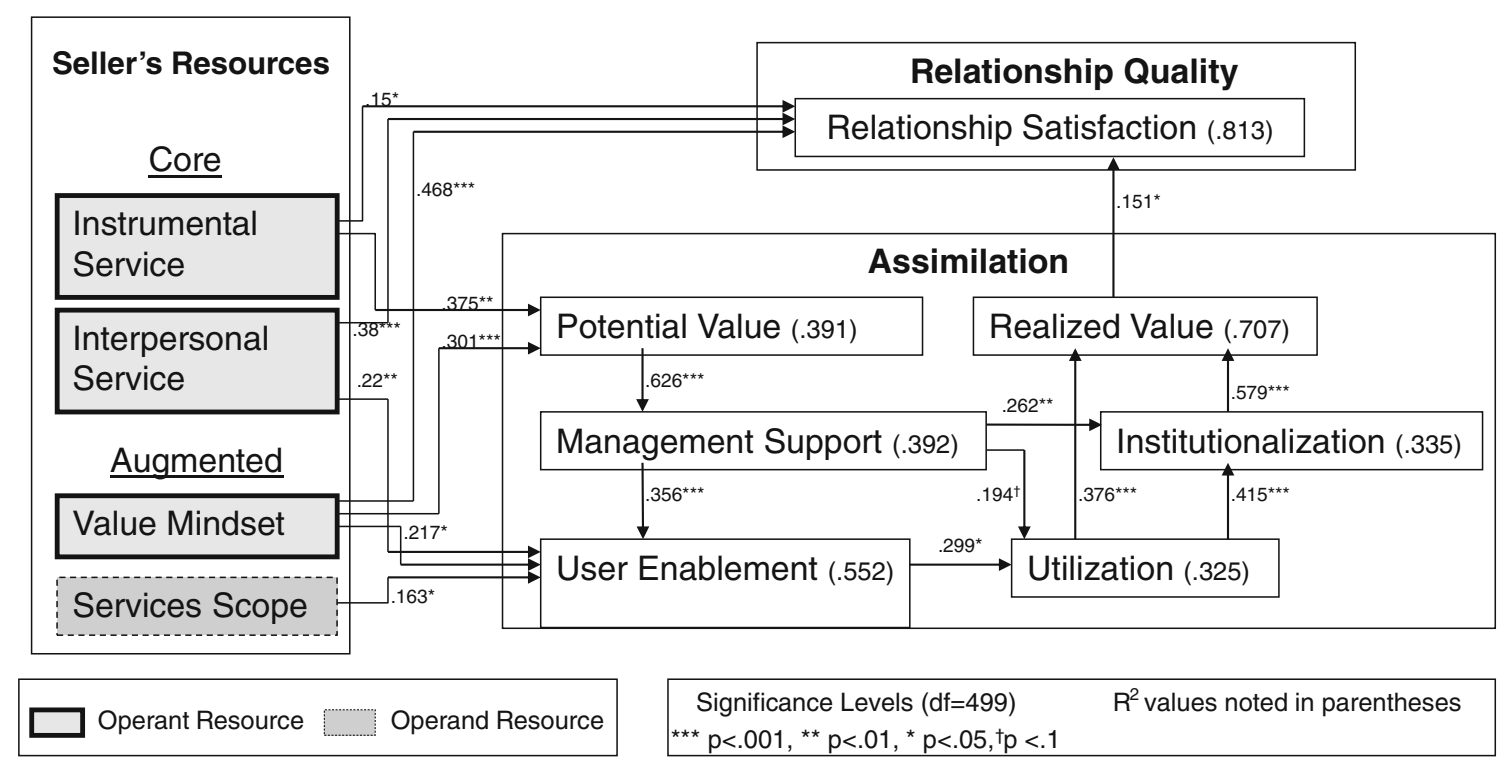

Fig. 4 Model result

relative effects on these leverage points appear comparable, suggesting that service augmentation is no less important than core domain excellence for sellers striving to help customers achieve assimilation.

Given the significant paths highlighted in Fig. 4, we determine the cumulative indirect effects on realized value attributable to each seller capability by calculating the composite path from each capability construct to realized value (the product of the relevant path coefficients, e.g., value mindset $\rightarrow$ potential value $\rightarrow$ management support $\rightarrow$ institutionalization $\rightarrow$ realized value $=.301 \times .626 \times .262 \times .579)$ and then summing across all the significant causal paths (Patterson et al. 1997). Given the number of links per path, and the standardized nature of the path coefficients, which range from zero to one, the absolute indirect effect for each construct will be small. However, the relative impact of different seller resources on assimilation results is still informative, given the research objectives for this study. Considering technical product expertise as a "minimum" buyer expectation for sellers, we set the cumulative impact of instrumental service on realized value as a benchmark value (sum of three significant composite paths from instrumental service to realized value $=0.051$, rescaled as index value $=1.0$ ). The relative effects of the various seller resources can then be viewed in Fig. 5 .

Based on these results, it appears that the operand resource services scope has only a secondary effect on assimilation
Fig. 5 Relative effects on realized value

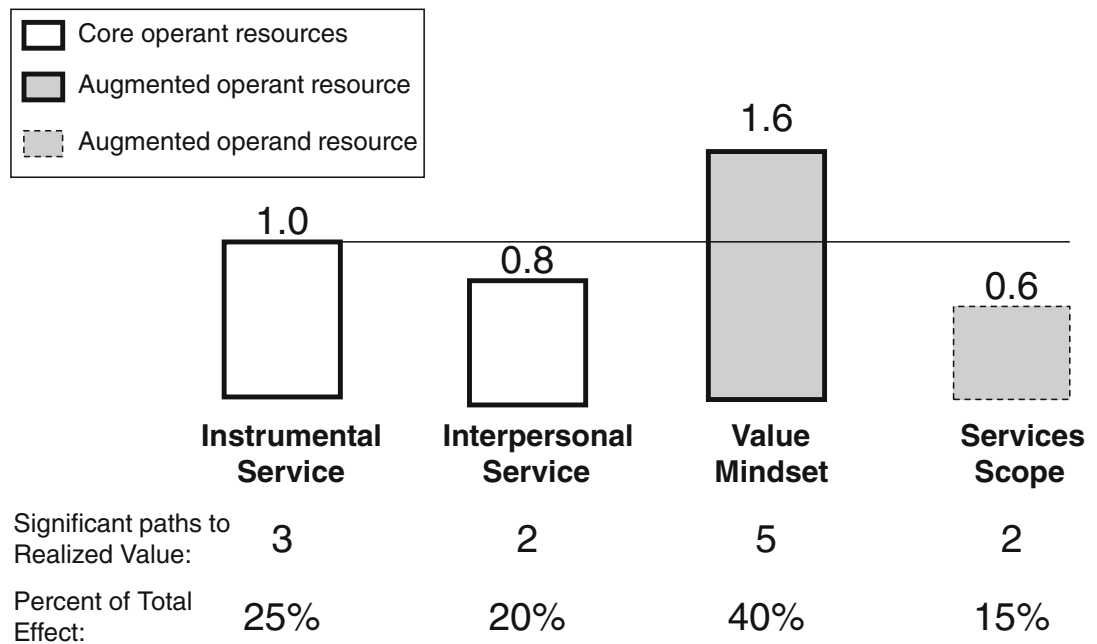


success and value. The most significant factor is value mindset, the augmented operant resource reflecting the seller's understanding of the buyer's path to value. Its contribution to realized value is 1.6 times that of instrumental service and double that of interpersonal service. Consequently, SH1a, $\mathrm{SH} 1 \mathrm{~b}$ and SH3a are supported.

This impact may be attributable in large part to the greater number of significant paths from value mindset to realized value (five paths for value mindset versus three for instrumental service and two for interpersonal service). Value mindset exhibits significant influence on both potential value and user enablement as leverage points to facilitate assimilation. In contrast, the influence of instrumental service and interpersonal service is limited to a single assimilation facilitator-potential value and user enablement respectively.

To the extent that sellers can convey a value mindset, irrespective of whether they monetize this mindset through formally contracted services (services scope), buyer expectations regarding the long-run potential of the technology (potential value) are enhanced. This results in more visible management support, intensified efforts to facilitate usage (user enablement), and greater likelihood of institutionalization-all of which contribute to greater economic value, as perceived by management (realized value).

Equally interesting is the question of whether economic value (realized value) matters as buyers form relationship-quality judgments about the seller. In this case, the influence of realized value on relationship satisfaction $\left(\beta_{R V} \rightarrow_{R S}=0.15\right)$ is relatively small - comparable to the effect of instrumental service $\left(\beta_{\mathrm{INST}} \rightarrow_{\mathrm{RS}}=\right.$ $0.15)$, and less than half the effect of interpersonal service $\left(\beta_{\mathrm{INTP}} \rightarrow_{\mathrm{RS}}=0.38\right)$ and value mindset $\left(\beta_{\mathrm{VM}} \rightarrow \mathrm{RS}=\right.$ $0.47)$. Thus, seller efforts to promote realized value through whatever means available (e.g., contracted services or informal advice) seem to matter less in the broader relationship satisfaction equation.

The smaller impact of realized value (RV) relative to the direct vendor antecedents of buyer's relationship satisfaction has face validity. The assimilation sub-model depicts the co-creation proposition of S-D logic with realized value being a function of both the vendor's and the buyer's efforts. For instance, implementation deficits and failure to attain the offering's full value potential could be due to internal buyer-attributed factors such as sub-optimal resource allocation, continued use of legacy processes rather than updated processes, or inertia. Given this co-creation aspect of realized value, buyers could be placing higher weight on factors directly controlled by the vendor in their assessment of relationship satisfaction with the vendor. Thus, the smaller effect size of realized value vis-à-vis factors under direct control of the vendor lends further credence to the co-creation aspect of S-D Logic.

The relative importance of core versus augmented resources is determined by both their direct and indirect effects on relationship satisfaction, although direct effects are the dominant factor. Combining both direct and indirect effects, and again setting instrumental service as the benchmark value (total effect $=0.158$, rescaled to 1.0 ), the relative influence of core versus augmented resources is illustrated in Fig. 6.

In terms of influence on overall relationship satisfaction, the services scope has negligible effect. The single most influential predictor of relationship satisfaction is value mindset. Its overall contribution to relationship satisfaction is three times that of instrumental service. Thus, even in situations in which the buyer chooses to have little or no services involvement with the seller as part of the BI implementation, the value mindset of the seller still has significant relational value, as manifested in greater relationship satisfaction. Consequently, $\mathrm{SH} 2 \mathrm{a}, \mathrm{SH} 2 \mathrm{~b}$, and $\mathrm{SH} 3 \mathrm{~b}$ are supported.
Fig. 6 Cumulative direct and indirect effects on relationship satisfaction

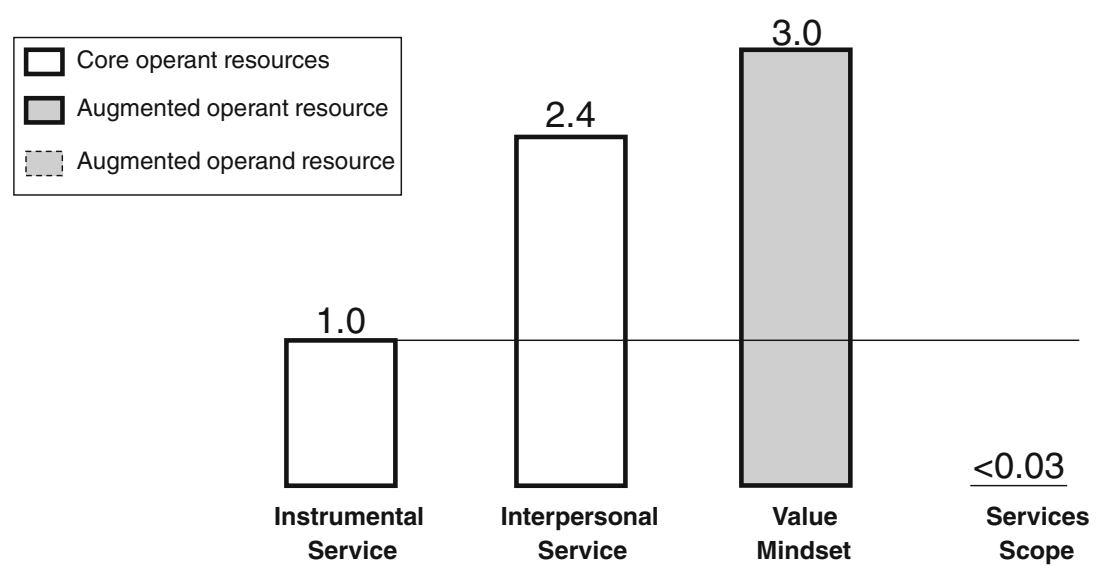




\section{Discussion}

The significant influence of value mindset as an augmented operant resource is consistent with the literature of product differentiation and customer satisfaction (Levitt 1980). In the context of this study, core seller operant resources including instrumental service and interpersonal service address minimum customer expectations. As long as these expectations are met, these core operant resources establish a base level of relationship satisfaction (Anderson 1973; Oliver 1980). However, augmented operant resources including value mindset are likely to help sellers exceed customer expectations, resulting in higher levels of relationship satisfaction, or customer "delight" (Oliver 1997). Today's increasingly knowledgeable and informed customers are looking to be wowed by novel revelations by the vendor and to learn about creative applications of the vendor's solution in their own business context (Adamson et al. 2012, 2013). While "delighting" customers might raise their expectations and make it more difficult to satisfy them in the future, Rust and Oliver (2000) find that a "delight" strategy can prove advantageous if satisfaction strongly influences future behavior - an effect we examine next.

\section{Customer loyalty}

The literature of customer satisfaction suggests that high levels of satisfaction are associated with desirable future behavior by customers. The buyer's overall or cumulative satisfaction with a seller - as opposed to transaction-specific satisfaction judgments - is widely regarded as an antecedent to future repurchase behavior (Patterson et al. 1997; Rosenbaum et al. 2006). More broadly, satisfaction promotes customer loyalty, reflected both in positive word-of-mouth and repurchase intent (Bolton et al. 2003; Lam et al. 2004).

With these effects in mind, we sought to investigate wordof-mouth and repurchase intent as consequences of relationship satisfaction. As these consequences were not critical to evaluating the primary research questions, and considering the length of the questionnaire, we chose to test a single-item word-of-mouth construct (willingness to recommend to other companies) and a single-item repurchase intent construct (willingness to do business in the future) in the final model. Although multi-item scales are important, there is research defending the use of single-item measures (Bergkvist and Rossiter 2007; Diamantopoulos et al. 2012).

As illustrated in Table 2, relationship satisfaction partially mediates the relationship between realized value and these two measures of customer loyalty.

Combining the results illustrated in Figs. 5 and 6 and in Table 2, we find that value mindset significantly affects the customer's beliefs regarding realized value and overall relationship satisfaction with the seller. These beliefs, in turn, have a strong influence on customer loyalty, reflected in favorable word-of-mouth and repurchase intent beliefs. Thus, augmented operant resources can have significant value - measured not only in relationship satisfaction, but also in future revenue prospects. These customer loyalty effects empirically underscore the critical importance and financial impact of soft service facets, and help to prioritize operant resource investments for organizations adopting S-D logic principles.

\section{Moderating influence of buyer sophistication on value mindset}

To better understand the conditions under which operant resources such as value mindset positively influence customer relationship satisfaction judgments, we evaluated characteristics such as third party services (scope of services provided by a firm other than the software product seller), size (number of employees), and buyer sophistication. To the extent that buyers differ in sophistication with respect to an offering, their need and desire for external assistance may vary (Barnes and McTavish 1983; Rai et al. 2012). Consequently, more sophisticated buyers would be expected to attach less value to soft service facets such as value mindset.

We utilized median splits of the dataset with respect to the third party services, size, buyer sophistication, and value mindset constructs in order to analyze their interactions in influencing relationship satisfaction. No significant interaction was observed $(\mathrm{F}(1119)=0.216$, n.s. $)$ between third party services and value mindset in terms of impact on relationship satisfaction. Only a marginally significant interaction was evident between size and value mindset on relationship satisfaction $(\mathrm{F}(1119)=3.758, p<0.1)$. But a much stronger relationship was evident with buyer sophistication. Univariate ANOVA analysis revealed a significant

Table 2 Relationship satisfaction - mediation tests

\begin{tabular}{|c|c|c|c|}
\hline Predictors & Without RS & With RS & Conclusion \\
\hline \multicolumn{4}{|c|}{ Mediating effects on word of mouth } \\
\hline \multicolumn{4}{|c|}{ Effect Size on WM } \\
\hline RV & $0.652 * *$ & $0.156^{*}$ & Partial mediation \\
\hline $\mathrm{RS}$ & & $0.782 * *$ & \\
\hline \multicolumn{4}{|c|}{ Mediating Effects on Repurchase Intent } \\
\hline \multicolumn{4}{|c|}{ Effect Size on RI } \\
\hline RV & $0.651 * *$ & $0.328 * *$ & Partial mediation \\
\hline $\mathrm{RS}$ & & $0.509^{* *}$ & \\
\hline
\end{tabular}

$R V$ Realized Value, $R S$ Relationship Satisfaction, $W M$ Word of Mouth, $R I$ Repurchase Intent

Significance levels (2-tailed test): $* * p<.001, * p<.01$

Tests based on procedure recommended by Baron \& Kenny (1986) 
two-way interaction $(\mathrm{F}(1119)=6.48, p<.05)$ between buyer sophistication and value mindset in terms of influence on relationship satisfaction (Fig. 7). Regression analysis with mean centered variables (Cronbach 1987) of buyer sophistication and value mindset on relationship satisfaction replicated the interaction effect.

Thus, the impact of value mindset on relationship satisfaction is accentuated for less sophisticated buyers.

\section{Interaction effects among operant resources}

Consistent with prior studies (Lai et al. 2013; Kumar 2002) we find both instrumental service and interpersonal service to be significant antecedents of relationship satisfaction. Given the even greater impact of value mindset, however, and the inter-connected nature of operant and operand resources in value co-creation, it is also important to understand potential interaction among the various operant resources. Accordingly, we conducted further univariate ANOVA tests based on median splits of the instrumental service, interpersonal service, and value mindset constructs. Analysis of the interactions of these constructs with relationship satisfaction did not identify significant interaction between instrumental service and interpersonal service $(F(1,119)=0.978$, n.s. $)$ or instrumental service and value mindset $(\mathrm{F}(1,119)=0.633$, n.s. $)$. This suggests that the impact of these constructs on relationship satisfaction is best represented as a main effects model. We did find a significant interaction between value mindset and interpersonal service $(\mathrm{F}(1,119)=7.285, p<.01)$ in terms of impact on relationship satisfaction (Fig. 8); however, a regression analysis was unable to confirm the interaction effect. We therefore view the effect as tentative.

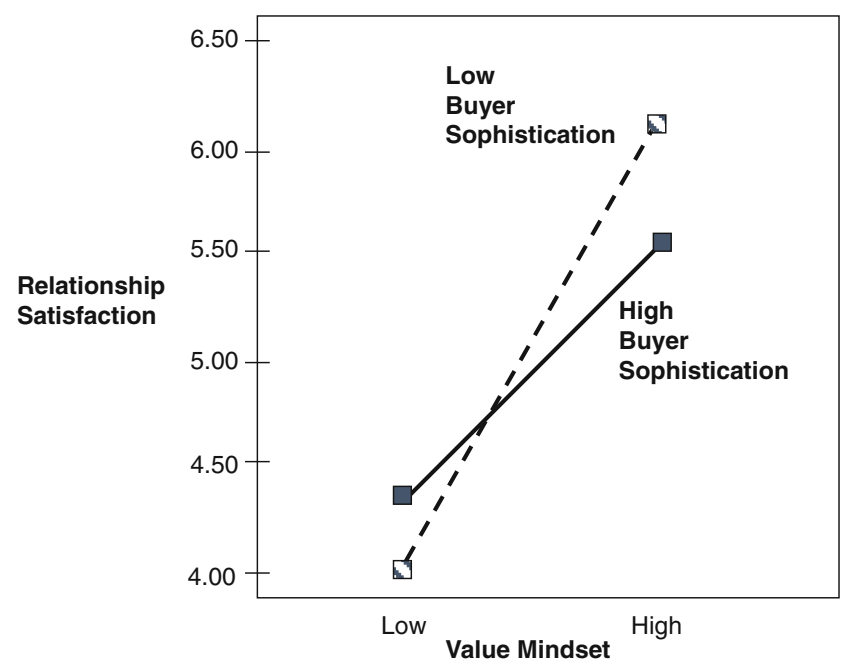

Fig. 7 Moderating influence of buyer sophistication
While instrumental service and interpersonal service constitute necessary core operant resources contributing independently to relationship satisfaction, value mindset (the augmented operant resource) may behave synergistically with interpersonal service to yield greater levels of relationship satisfaction.

\section{Implications}

Given the complexity of managing hybrid goods-services companies, it is important to understand the incremental value of adding a services element to a goodsdominant business model. The results of this study support the wisdom of software companies augmenting their business models with services. The results also reveal that different facets of the services domain have different associations with customer-specific outcomes. The actual scope of services provided seems to have little influence on either technology assimilation or the customer's ultimate judgments of relationship quality. This result aligns with that of Oliva et al. (2012), who find no impact of expanded services scope on customer satisfaction. While some authors argue for a balance of goods and services in the offering mix, the primary rationale for adding services to the core goods model appears to be revenue diversification aimed at helping sellers to weather adverse business cycles (Cusumano 2003). Furthermore, customers may value buyer-seller interactions facilitated by a services relationship more highly than core product attributes (Vandenbosch and Dawar 2002). Consequently, while developing a services business may be attractive for some goods-dominant

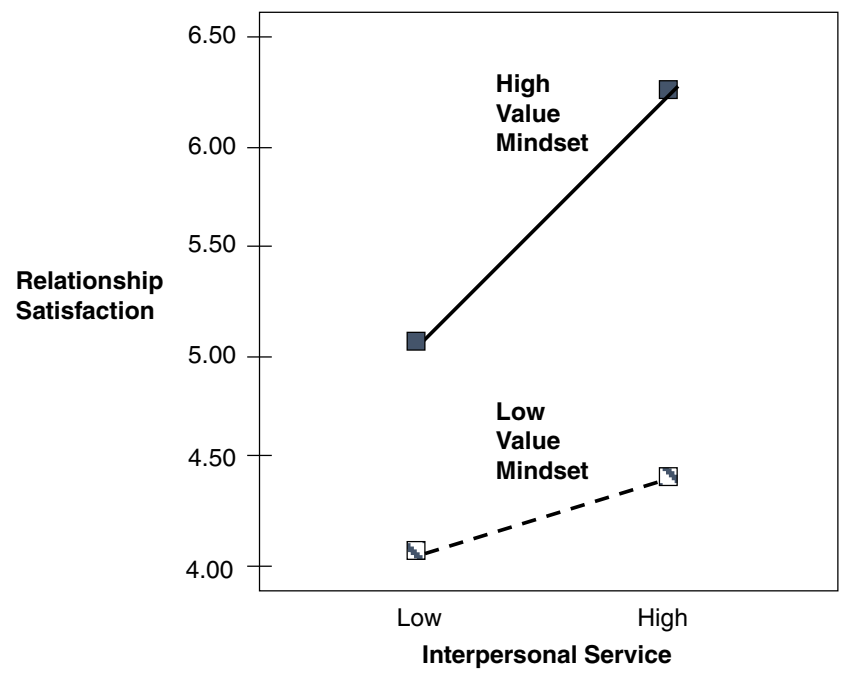

Fig. 8 Interaction of value mindset and interpersonal service 
companies, this study shows that simply offering more services does little to enhance customer relationships, and that firms need to look elsewhere to justify investments to expand services.

In contrast, the mindset that a seller brings to a customer relationship has a strong positive influence on both technology assimilation and relationship satisfaction. Our results indicate that sellers who convey a customer value-oriented mindset beyond product domain mastery and good interpersonal service earn higher levels of customer relationship satisfaction, in turn resulting in more positive word-of-mouth and greater repurchase intent. This result is magnified for buyers with less prior experience with the relevant technology.

These findings confirm prior work establishing customer value as a predictor of relationship satisfaction (Eggert and Ulaga 2002; Sengupta et al. 2000) and underscore a critical dimension of the broad concept of service quality in B2B settings (Lapierre 2000; Menon et al. 2005). However, where prior work has concentrated on seller behaviors and policies (e.g., decisionmaking processes and lateral/horizontal interactions) with the potential to leverage perceived customer value (Georges and Eggert 2003), this study examines the customer value "mindset" that sellers exhibit-a more difficult-to-imitate operant resource. Just as prior work has established the influence of customer orientation on relationship quality at the interpersonal level (Macintosh 2007), this study demonstrates a comparable firm-level effect for the S-D logic-based construct, value mindset.

Moreover, while value mindset, viewed in isolation, exhibits a stronger influence on relationship satisfaction than either interpersonal service or instrumental service, there is also directional evidence for synergistic interactions when value mindset is involved. Coupling interpersonal service and value mindset may have the potential to intensify the impact on relationship satisfaction beyond their individual effects. The markedly different impacts identified in this study for services scope versus value mindset underscore and empirically reinforce a subtle but important aspect of the S-D logic framework: it is not the services per se that influence customer perceived value and relationship quality, but rather the service mindset which is manifested in customer value terms (Vargo and Lusch 2008b, c).

For software companies striving to find the right balance in their goods-services mix, these results have important implications. First, services business units within such companies will likely need to earn continued corporate commitment based on their standalone financial contribution. Only minimal additional customer relationship benefits are apparent. Because this study finds no clear relationship quality arguments for subsidizing services, we conclude that the pricing of such services should be in line with corporate targets for margin contribution, as opposed to the heavily discounted or "free" services pricing often employed to differentiate core product offerings.

Second, the marginal effect that scope of services has on customer satisfaction provides validation for the practice that many software firms have adopted of forming partnerships with third-party service providers (Hoch et al. 2000; Mohr et al. 2005). Contrary to the perceived need for software companies to offer a "onestop shop," encompassing both software and services, this study finds no particular disadvantage to a "best of breed" alliance approach. In fact, the more clarity software companies can bring to the customer's plan for value creation (including additional third-party resource requirements), the greater the relationship satisfaction they are likely to generate. This approach to customer value creation is consistent with the advice of Vandenbosch and Dawar (2002, p. 40), who call for companies to be the "nexus" or "market maker" for value for their customers, serving as "the link between customers and the sellers of complementary products and services."

Third, in formalizing alliance relationships with thirdparty service providers, software companies should look beyond tactical sales development opportunities to exploit inter-firm learning opportunities (Lusch et al. 2010; Mohr and Sengupta 2002) to develop and articulate comprehensive value "blueprints" or "roadmaps" they can share with customers. Comparable insights could also be gleaned from other structures or initiatives aimed at infusing customer perspectives into the seller's organization (e.g., customer representation on the board of directors, involvement in buyer councils or user groups, or use of experienced, external hires to augment the firm's grasp of customer value). At any point in time, such holistic value perspectives (value mindset) are likely to have greater influence on customer relationship satisfaction than the actual project results (realized value).

These findings are especially important in weighing decisions over the long term. Businesses are under intense pressure to conserve resources and allocate scarce capital in order to achieve maximum strategic and financial benefit with least risk. In many organizations, the burden of growth falls on a shrinking, stretched workforce. Human capital investments are often the first casualty in budget reduction (Huang and Rust 2014; Rust and Huang 2012). This study strikes a cautionary note against this practice and suggests that 
human capital investments (e.g., enhancing the value mindset) can pay long-term dividends in stronger customer relationships, which in turn promote more positive word-of-mouth and more favorable customer repurchase intent.

\section{Contributions}

This study makes important contributions to understanding the relative influence of "soft" versus "hard" service assets. In particular, the study provides empirical evidence of the value of human capital investments - as opposed to tangible services offerings - as a means of strengthening relationship quality.

From an academic perspective, the study constitutes, to the best of our knowledge, the first empirical evaluation in the S-D logic literature of the differential impact of operant versus operand resources. It provides an initial quantified perspective on the influence of what Madhavaram and Hunt (2008) term "interconnected" operant resources that hold the potential to become "masterful" operant resources. The study brings together previously disparate perspectives from the technology management and marketing disciplines to create a new, holistic framework linking seller resources with buyer technology assimilation results that help capture S-D logic's co-creation of value element. Adopting a buyer's perspective, the study is largely consistent with Tuli et al.'s (2007) powerful qualitative findings, where buyers view customer solutions through a relational processes lens as opposed to an integrated customized goods-services lens, typical of sellers.

From a practitioner perspective, the study can help organizations make more informed decisions about the optimal mix of services in their business model and how best to focus their human capital development. The study's findings on customer technology assimilation and the relative effect of core versus augmented resources on buyer-seller relationship quality should be helpful to businesses confronting these challenges. The insights of the study are derived from a buyer-centered view of project outcomes, providing a fresh view of how relationship quality can be improved. The implication for enterprise software companies-and hybrid goods-services companies in general-is that investments in human capital that facilitate a holistic customer value mindset have a significant impact on relational performance.

\section{Limitations and suggestions for future research}

Given that this is one of the first studies to empirically test the operant and operand resource concept within the
S-D logic paradigm, there are limitations that point to avenues for future inquiry. First, due to its exploratory nature, the study's conclusions are based on a crosssection of customer experiences in a rapidly evolving technology context. A longitudinal assessment of dynamic, cumulative constructs such as realized value and relationship satisfaction could be illuminating. Second, the study design focuses on buyer perceptions of the seller's resources. To capture a more objective perspective, it might be fruitful to investigate the relationship between seller resources and buyer assimilation results and relationship quality judgments in a dyadic context, with data collected from all the relevant stakeholders on both sides of the buyer-seller dyad. Third, given the criticality of value mindset, it is important to examine the drivers of value mindset development and activation to help organizations take steps to facilitate development of this augmented operant resource. Fourth, there are opportunities to integrate other research on the relationship quality effects of seller organizational capabilities. For instance, Sengupta et al. (2000) point to "intrapreneurial ability" (a salesperson's entrepreneurial behaviors exercised inside his or her firm) as a driver of customer relationship outcomes. Relatedly, the qualitative research findings of $\mathrm{Neu}$ and Brown (2005) suggest that human resources flexibility (e.g., the ease with which multiple business unit efforts or staff can be engaged to address customer-specific needs) is a characteristic of successful B2B service providers. Therefore, future research focused on the joint effect of organizational flexibility and a services mindset would be useful. Fifth, while this study offers an initial, limited view on the relationship between seller resources and customer loyalty measures such as word-of-mouth and repurchase intent, further examination of the consequences of relationship quality and their connection to seller resources is warranted. Finally, it would be instructive to explore other product categories besides business intelligence systems, as well as other contingent factors, including other buyer-seller relationship factors and the buyer's competitive and IT context.

Acknowledgments The authors thank members of the 2007 Fisher IMS / AMA SERVSIG Dissertation Proposal Competition committee and the ISBM Dissertation Proposal Competition Committee for their invaluable feedback and comments. In addition, the authors thank the MSI review team for their crucial feedback and research sponsorship. Anne Hoekman's support through the review process is also greatly appreciated. Finally, the authors thank John Hauser, Ajay Kohli, A. Parasuraman, Bill Ross, Lisa Scheer, Duncan Simester, and the editor and review team at JAMS for their most insightful feedback and comments. 


\section{Appendix 1}

Table 3 Theoretical constructs and measurement Items

\begin{tabular}{|c|c|c|c|}
\hline Construct & Item code & Definition and measurement items & Supporting literature \\
\hline \multirow[t]{6}{*}{ Potential Value } & & $\begin{array}{l}\text { Prevailing beliefs within the buying organization } \\
\text { as to the innovation's long term potential for } \\
\text { value creation, net of implementation costs } \\
\text { and risks }\end{array}$ & \multirow[t]{6}{*}{$\begin{array}{l}\text { Chircu and Kauffman 2000; } \\
\text { Davern and Kauffman } 2000\end{array}$} \\
\hline & PV1 & $\begin{array}{l}\text { We believe the BI system has the potential to } \\
\text { create significant economic value for our } \\
\text { organization }\end{array}$ & \\
\hline & PV2 & $\begin{array}{l}\text { We believe the BI system has the potential to } \\
\text { streamline the process for getting users the } \\
\text { information they need. }\end{array}$ & \\
\hline & PV3 & $\begin{array}{l}\text { We believe the BI system has the potential to } \\
\text { improve the quality of information our staff } \\
\text { use in performing their work. }\end{array}$ & \\
\hline & PV4 & $\begin{array}{l}\text { Over its lifetime, we expect the BI system to be } \\
\text { well worth its total cost to implement and } \\
\text { operate. }\end{array}$ & \\
\hline & PV5 & $\begin{array}{l}\text { We feel confident the potential benefits of BI } \\
\text { are achievable for our organization. }\end{array}$ & \\
\hline \multirow[t]{4}{*}{ Management support } & & $\begin{array}{l}\text { The extent to which senior executives or key } \\
\text { influencers within the buying organization } \\
\text { actively champion the assimilation of the } \\
\text { innovation }\end{array}$ & \multirow[t]{4}{*}{$\begin{array}{l}\text { Agarwal et al. 1997; } \\
\text { Kwon and Zmud } 1987\end{array}$} \\
\hline & MS6 & $\begin{array}{l}\text { Top management considers the BI system } \\
\text { important to our organization. }\end{array}$ & \\
\hline & MS7 & $\begin{array}{l}\text { Top management voices clear support for } \\
\text { the BI system. }\end{array}$ & \\
\hline & MS8 & $\begin{array}{l}\text { Top management actively champions adoption } \\
\text { of the BI system. }\end{array}$ & \\
\hline
\end{tabular}

User enablement

The degree to which user-level obstacles to adoption and use have been addressed, such that the innovation can be diffused to everyone able to use it to the advantage of the enterprise

We provide users with the resources and support they need to use the BI system.

We ensure users possess the knowledge required to use the BI system.

We work to reduce obstacles to adopting the BI system.

Our technology environment makes it easy for users to adopt the BI system.

Utilization

The breadth and intensity of the innovation's usage within the buying organization

The BI system is used by many groups across our organization.

UT17

Institutionalization
The BI system serves a variety of purposes for our organization.

The degree to which the buying organization views the innovation as a platform for future development and investment

Going forward, we see the current BI system as a platform for future expansion.

We have allocated funds in our budget to enhance the BI system.
Mathieson et al. 2001

Burton-Jones and Straub 2006;

Shih and Venkatesh 2004

Meyer and Goes 1988 
Table 3 (continued)

\begin{tabular}{|c|c|c|c|}
\hline Construct & Item code & Definition and measurement items & Supporting literature \\
\hline \multirow[t]{7}{*}{ Realized value } & & $\begin{array}{l}\text { The buyer's assessment of the overall economic } \\
\text { value resulting from the acquisition and } \\
\text { implementation of the seller's innovation, } \\
\text { along with any associated business changes }\end{array}$ & \multirow[t]{7}{*}{$\begin{array}{l}\text { Anderson and Narus 1998; } \\
\text { Davern and Kauffman } 2000\end{array}$} \\
\hline & IN25 & $\begin{array}{l}\text { The BI system has become integral to the } \\
\text { way we run our business. }\end{array}$ & \\
\hline & IN26 & $\begin{array}{l}\text { The BI system helps us make decisions based } \\
\text { on more consistent information. }\end{array}$ & \\
\hline & IN27 & $\begin{array}{l}\text { The BI system has helped us gain new insights } \\
\text { about our business }\end{array}$ & \\
\hline & RV28 & $\begin{array}{l}\text { Based on results to date, the BI system has } \\
\text { helped our organization become more } \\
\text { profitable. }\end{array}$ & \\
\hline & RV29 & $\begin{array}{l}\text { The BI system has improved our overall } \\
\text { competitiveness. }\end{array}$ & \\
\hline & RV30R & $\begin{array}{l}\text { Considering its total costs to date, the BI system } \\
\text { investment has yet to achieve a positive return } \\
\text { on investment (ROI). [reversed] }\end{array}$ & \\
\hline \multirow[t]{12}{*}{ Services scope (formative) } & & $\begin{array}{l}\text { The scope of services provided by the seller to } \\
\text { support and augment the buyer's purchase } \\
\text { of the innovation }\end{array}$ & \multirow[t]{12}{*}{$\begin{array}{l}\text { Davern and Kauffman 2000; } \\
\text { Davies et al. } 2006\end{array}$} \\
\hline & SS32A & $\begin{array}{l}\text { We rely on the BI system vendor to help us to: } \\
\text { Integrate the BI system with our existing } \\
\text { systems }\end{array}$ & \\
\hline & SS32B & $\begin{array}{l}\text { We rely on the BI system vendor to help us to: } \\
\text { Resolve problems which arise with the BI } \\
\text { system operations }\end{array}$ & \\
\hline & $\mathrm{SS} 32 \mathrm{C}^{*}$ & $\begin{array}{l}\text { We rely on the BI system vendor to help us to: } \\
\text { Implement planned upgrades to the BI system }\end{array}$ & \\
\hline & SS32D* & $\begin{array}{l}\text { We rely on the BI system vendor to help us to: } \\
\text { Upon our request, implement modifications } \\
\text { to the BI system }\end{array}$ & \\
\hline & SS32E* & $\begin{array}{l}\text { We rely on the BI system vendor to help us to: } \\
\text { Manage the BI system implementation process }\end{array}$ & \\
\hline & $\mathrm{SS} 32 \mathrm{~F}^{*}$ & $\begin{array}{l}\text { We rely on the BI system vendor to help us to: } \\
\text { Assess our BI training needs }\end{array}$ & \\
\hline & $\mathrm{SS} 32 \mathrm{G}^{*}$ & $\begin{array}{l}\text { We rely on the BI system vendor to help us to: } \\
\text { Provide training for users of the BI system }\end{array}$ & \\
\hline & $\mathrm{SS} 32 \mathrm{H}$ & $\begin{array}{l}\text { We rely on the BI system vendor to help us to: } \\
\text { Design changes in our business processes to } \\
\text { make better use of the system }\end{array}$ & \\
\hline & SS32I* & $\begin{array}{l}\text { We rely on the BI system vendor to help us to: } \\
\text { Define job changes in our organization to } \\
\text { make better use of the system }\end{array}$ & \\
\hline & SS32J* & $\begin{array}{l}\text { We rely on the BI system vendor to help us to: } \\
\text { Define business strategy changes for our } \\
\text { organization to make better use of the system }\end{array}$ & \\
\hline & * Formativ & due to non-significant regression weight in the PLS outer model & \\
\hline \multirow[t]{5}{*}{ Instrumental service } & & $\begin{array}{l}\text { The degree of technical mastery exhibited by } \\
\text { the seller's staff with respect to the core } \\
\text { product }\end{array}$ & \multirow{5}{*}{$\begin{array}{l}\text { Abdul-Muhmin 2005; } \\
\text { Chumpitaz \& Paparoidamis 2004, } \\
\text { Gronroos 1984; } \\
\text { Homburg and Rudolph } 2001\end{array}$} \\
\hline & PK34 & $\begin{array}{l}\text { Our BI vendor has strong technical expertise } \\
\text { in the field of BI solutions. }\end{array}$ & \\
\hline & PK35 & $\begin{array}{l}\text { Our BI vendor clearly differentiates the quality } \\
\text { of his/her solution from that of competitors. }\end{array}$ & \\
\hline & PK36 & $\begin{array}{l}\text { Our vendor understands the current state of } \\
\text { the BI market. }\end{array}$ & \\
\hline & PK37 & $\begin{array}{l}\text { Our vendor has a compelling vision of the } \\
\text { future of BI. }\end{array}$ & \\
\hline
\end{tabular}


Table 3 (continued)

\begin{tabular}{|c|c|c|c|}
\hline Construct & Item code & Definition and measurement items & Supporting literature \\
\hline \multirow[t]{6}{*}{ Interpersonal service } & & $\begin{array}{l}\text { The degree to which the seller exhibits } \\
\text { service-giving behaviors indicative of close } \\
\text { attention to customer needs }\end{array}$ & \multirow{6}{*}{$\begin{array}{l}\text { Abdul-Muhmin 2005; } \\
\text { Chumpitaz \& Paparoidamis } 2004 \\
\text { Gronroos 1984; } \\
\text { Parasuraman et al. } 1985\end{array}$} \\
\hline & SO38R & $\begin{array}{l}\text { We sometimes find it difficult to get a quick } \\
\text { response from the vendor to our requests. } \\
\text { [reversed] }\end{array}$ & \\
\hline & SO39 & The vendor gets things done right the first time. & \\
\hline & $\mathrm{SO} 40$ & The vendor keeps his/her promises. & \\
\hline & $\mathrm{SO} 41$ & The vendor communicates effectively with us. & \\
\hline & $\mathrm{SO} 42$ & $\begin{array}{l}\text { The vendor is helpful in terms of assisting us } \\
\text { to solve problems. }\end{array}$ & \\
\hline \multirow[t]{5}{*}{ Value mindset } & & $\begin{array}{l}\text { The degree to which the seller understands the } \\
\text { buyer's business context, and the opportunity } \\
\text { for the innovation to add value in that context }\end{array}$ & \multirow[t]{5}{*}{$\begin{array}{l}\text { Abratt and Kelly 2002; } \\
\text { Dawar and Vandenbosch 2004; } \\
\text { Sengupta et al. } 2000\end{array}$} \\
\hline & VM43 & $\begin{array}{l}\text { The vendor understands how BI can add value } \\
\text { to our business. }\end{array}$ & \\
\hline & VM44 & $\begin{array}{l}\text { The vendor understands the scope of change } \\
\text { required in our business to realize value } \\
\text { from BI. }\end{array}$ & \\
\hline & VM45 & $\begin{array}{l}\text { The vendor shares best practices of other } \\
\text { organizations in creating value from BI. }\end{array}$ & \\
\hline & VM46 & $\begin{array}{l}\text { The vendor conveys lessons learned by } \\
\text { other organizations which have struggled } \\
\text { to realize value from BI. }\end{array}$ & \\
\hline \multirow[t]{5}{*}{ Relationship satisfaction } & & $\begin{array}{l}\text { The buyer's overall assessment of the } \\
\text { productivity, worth, and positive affect } \\
\text { associated with the seller relationship }\end{array}$ & \multirow[t]{5}{*}{$\begin{array}{l}\text { Abdul-Muhmin 2005, } \\
\text { Hausman 2001; } \\
\text { Walter et al. } 2003\end{array}$} \\
\hline & RS47 & $\begin{array}{l}\text { Our BI vendor has been a good company } \\
\text { to do business with. }\end{array}$ & \\
\hline & RS48 & $\begin{array}{l}\text { We feel satisfied with the offerings provided } \\
\text { by our BI vendor. }\end{array}$ & \\
\hline & RS49 & $\begin{array}{l}\text { All in all, our BI vendor has been very fair } \\
\text { to us. }\end{array}$ & \\
\hline & RS50 & $\begin{array}{l}\text { Overall, we are satisfied with our relationship } \\
\text { with our BI vendor. }\end{array}$ & \\
\hline \multirow[t]{4}{*}{ Buyer sophistication } & & $\begin{array}{l}\text { The buyer's prior knowledge and experience } \\
\text { with the innovation. }\end{array}$ & \multirow[t]{4}{*}{$\begin{array}{l}\text { Barnes and McTavish 1983, } \\
\text { Green et al. } 1994\end{array}$} \\
\hline & BS9R & $\begin{array}{l}\text { As an organization, we had very little experience } \\
\text { with BI before implementing the current } \\
\text { system. [reversed] }\end{array}$ & \\
\hline & BS10 & $\begin{array}{l}\text { Within our organization, we had individuals } \\
\text { with significant knowledge of BI even } \\
\text { before we implemented the system. }\end{array}$ & \\
\hline & BS11 & $\begin{array}{l}\text { Based on the expertise of our buying team, } \\
\text { we had specific, detailed requirements } \\
\text { in mind for our BI system. }\end{array}$ & \\
\hline
\end{tabular}

\section{Appendix 2}

Appendix 1 lists operational definitions, measurement items, and supporting literature for each construct in the research model. Seller capabilities include core operant resources (instrumental service and interpersonal service) and augmented capabilities (the operant resource, value mindset, and the operand resource services scope). These are posited to affect relationship satisfaction directly, and indirectly through the assimilation constructs - in particular potential value, which gauges the buyer's sense of the "promise" of the technology (Davern and Kauffman 2000), and user enablement, which 
captures the buyer's explicit inclination to facilitate widespread adoption of the technology within the organization (Mathieson et al. 2001).

\section{Seller capabilities directly influence relationship satisfaction}

Relationship satisfaction represents the buyer's overall assessment of the productivity, worth, and positive affect associated with the seller relationship (Walter et al. 2003). The literature of B2B relationship marketing, and in particular, key account management (KAM), provides support for a direct effect of seller capabilities on relationship satisfaction $(\mathrm{H} 1 \mathrm{a}, \mathrm{H} 1 \mathrm{~b}, \mathrm{H} 1 \mathrm{c})$. Instrumental service and interpersonal service stand at the heart of B2B customer value models (Homburg et al. 2005). Instrumental service - the degree of technical mastery exhibited by the seller's staff with respect to the core product, and a key element of transactional quality (Homburg and Rudolph 2001) has a significant influence on relationship satisfaction (Bruhn and Frommeyer 2004). Empirical support for vendor knowhow on relational value is evidenced in Ulaga and Eggert (2006b) as well (H1a). Similarly, interpersonal service (the seller's expressive performance of "service-giving" behaviors; Gronroos 1984; Lytle et al. 1998) is a significant factor directly influencing relationship satisfaction (Abdul-Muhmin 2005). Ulaga and Eggert (2006b) also evidence the importance of interpersonal interactions for relationship value (H1b).

Value mindset represents the degree to which the seller understands the buyer's business context and the technology's value creation potential in that context (Abratt and Kelly 2002; Dawar and Vandenbosch 2004). From a buyer's perspective, Pardo (1997) notes that aligning the seller's key account management (KAM) approach (e.g., enhancing global competitiveness through global standardization of purchased goods / services) with the buyer's strategic objectives enhances KAM effectiveness and the quality of the buyer-seller relationship. Thus, understanding the buyer's concept of "value" (a value mindset orientation), and reflecting that understanding in the overall sales approach will have a positive effect on relationship quality (H1c). This view is echoed by Walter et al. (2003), who find relationship quality is driven both by "direct" functions (e.g., delivering a quality product, conducting business efficiently, etc.) and "indirect" functions such as providing industry-level perspectives (e.g., best practices) and suggesting new ideas for innovation.

Value mindset is especially pertinent in today's business environment with increasingly informed and knowledgeable customers who are not only cognizant of their needs but also potential solutions (Adamson et al. 2012, 2013). In this challenging selling environment, with many B2B buyers having completed $60 \%$ of their purchasing decision before they talk to a seller (Adamson et al. 2012), buyers increasingly value sellers who understand their business context, offer novel insights in that context and share relevant knowledge to help them gain a competitive edge (Adamson et al. 2013). Thus, we propose:

H1: A seller's (a) instrumental service, (b) interpersonal service, and (c) value mindset each have a direct positive influence on relationship satisfaction.

\section{Seller capabilities positively influence potential value and management support}

Value, as reflected in anticipated efficiency or profitability gains, is a clear driver of many organizational technology adoption decisions. The relationship management literature suggests that a seller's instrumental service and interpersonal service will have a significant influence on perceived value assessments, particularly early in the relationship lifecycle (Eggert et al. 2006). To the degree that a seller's instrumental service and interpersonal service help to convey the product's benefits and support commitment - sufficient to have warranted organizational adoptionthe offering is more likely to meet customer expectations for potential value (H2a, $\mathrm{H} 2 \mathrm{~b})$.

Beyond this "core" product-oriented capability, value mindset represents an "augmented" capability sellers may strive to develop. A seller's value mindset will positively influence buyer perceptions of potential value. Managers are ultimately concerned as much or more with the holistic use-related value that innovations promise, as with any measures of their intrinsic, standalone value, or perceptual benefits positioning, absent costs (Urban and Hauser 1993). A seller's value proposition should reflect all the benefits associated with its offering, and ideally, all of the benefits pertinent to a particular buyer (Sengupta et al. 2000). In the case of IT investments in particular, the role of "complementary assets" is pivotal in determining ultimate financial outcomes (Davern and Kauffman 2000). Consequently, the potential value which matters most to managers should incorporate the comprehensive net benefit to the organization, in light of "limits to value" or other complementary investments they will likely need to make (Chircu and Kauffman 2000).

Given the buyer's aversion to technology risks, and natural inclination to favor trusted technology sellers with proven track records (Woodside 1996), a seller with a "total value" perspective grounded persuasively in the experience of other companies (e.g., "best practices" of successful innovators, or "lessons learned" from less successful initiatives) will be viewed more favorably by most buyers (Dawar and Vandenbosch 2004). Thus, to the extent that a seller exhibits a more significant and comprehensive value mindset, buyers are more likely to perceive the seller's proposed project as possessing higher potential value $(\mathrm{H} 2 \mathrm{c})$.

Finally, a seller's services scope, another augmented capability, can significantly influence buyer potential value judgments. Services scope includes product-augmenting services 
such as training, change management, and implementation support (Alexander and Hordes 2003). These services have the potential to influence both the impact of a potential project, and its feasibility or risk. Consequently, services-supported projects may rank higher in project prioritization frameworks that emphasize impact and feasibility as key considerations (Melville et al. 2004; Wen and Shih 2006). For IT consulting services in particular, firms look to address internal IT capability shortfalls, and procure services with an expectation of performance and value benefits (Iyer et al. 2006). Services scope, therefore, can enhance the perception of feasibility for an IT-enabled change initiative, and thereby increase its perceived potential value within the buying organization $(\mathrm{H} 2 \mathrm{~d})$. Thus, we propose:

H2: A seller's (a) instrumental service, (b) interpersonal service, (c) value mindset, and (d) services scope each have a direct positive influence on the perceived potential value of the offering

As perceived potential value increases, so then for most organizations does management support- the extent to which senior executives actively champion assimilation of the technology (Agarwal et al. 1997). "Rational" managers are assumed to be utility maximizers who assess the attributes of potential purchase options, weighted by the importance they attach to those attributes (Kauffman and Popkowski-Leszczyc 2005). Thus, at the technology adoption stage, involved, rational managers may be presumed to have evaluated the technology favorably against the organization's purchase criteria, including perceived potential value. Management support for a project, and project funding authorization resulting from an IT prioritization process, are related, if not equivalent concepts. In the specific case of data warehouse implementations, management support has proven essential to ensure that financial and human resources commitments are sustained over the life of the project (Wixom and Watson 2001). Given that potential value (reflecting both measures of impact and feasibility) influences investment decisionmaking and project prioritization, it should positively influence management support (H3). Consequently, we propose:

H3: The perceived potential value of the offering has a direct positive influence on management support.

\section{Seller capabilities positively influence user enablement}

User enablement represents the degree to which user-level obstacles to adoption and use (e.g., understanding, required skills, physical access) have been addressed, such that the technology can be diffused to everyone able to use it to the advantage of the enterprise. Agarwal et al. (1997, p. 350) define a typology of strategies for assimilating technologies in organizations including top management support and "advocacy," which they define as making the technology "an integral part of the target audience's regular work behavior through job redesign" and imparting "needed knowledge about the technology through training and experimentation." Advocacy aligns with the computer self-efficacy concept from the MIS literature (Mathieson et al. 2001) which suggests that an individual's beliefs about his or her ability to use an information system, coupled with available resources, influence his or her attitude toward and actual use of the system. The user enablement construct is a composite of these factors, reflecting proactive management efforts to remove user adoption obstacles, enhance user confidence in using the system, and establish a work context which encourages usage. Consequently, management support is a critical antecedent of user enablement (H4). Thus,

H4: Management support has a direct positive influence on user enablement.

From a seller perspective, though, each of the complementary capabilities is also positioned to influence user enablement. A seller exhibiting low instrumental service and interpersonal service would surely add to the user enablement burden in a buying organization, as user questions and concerns would be more difficult to address (H5a, H5b). Conversely, a seller with a strong value mindset, including a detailed understanding of the organizational or process change requirements the buyer faces to realize value, could provide critical assistance in planning for user enablement (H5c). Similarly many of the constituent services underlying services scope are intended to directly support user enablement (H5d), based on enhanced organizational learning or other reductions in barriers to enterprise-wide adoption. Thus, we propose:

H5: A seller's (a) instrumental service, (b) interpersonal service, (c) value mindset, and (d) services scope each have a direct positive influence on user enablement.

\section{User enablement and management support positively influence utilization}

The relationship between user enablement and utilization (the breadth and intensity of usage across the organization (Burton-Jones and Straub 2006)) is suggested in much of the MIS literature (H6a). Mathieson et al. (2001) find that "perceived user resources" including access to computing resources, personal knowledge, time, and availability of support are significant predictors of system usage. These findings are consistent with Mahmood and Swanberg's (2001) concept of "organizational support" which emphasizes both enablement and encouragement by management, and with Anakwe et al.'s 
(2000) analysis of organizational support and IT usage. Training efforts are a particularly important element of user enablement. Simon et al. (1996) examine differences in the impact of "exploration learning" (user-driven self-teaching) and "instruction-based learning" (proactive, instructor-driven teaching) and find that the latter enhances user proficiency with IT based on a more complete "mental model" of the application, leading to both increased usage and higher levels of satisfaction.

Similarly, the MIS and innovation diffusion literature streams are clear with respect to the influence of management support on utilization. Organizational users are influenced (at least initially) by subjective norms such as obedience to authority (Cooper and Bhattacherjee 2001), shared group goals (Frank et al. 2004), and social pressures (Igbaria et al. 1996). To the extent that management support contributes to group norms favoring adoption, and clarifies the linkage between system use and organizational goals (enhancing perceived usefulness), utilization is influenced positively (Igbaria et al. 1997; Kwon and Zmud 1987). Management support may also contribute to changing user attitudes or feelings such as fear, inertia, reluctance to abandon traditional tools, and anxiety about task or role changes brought about by new technology, all of which have been identified as significant factors in the non-adoption of innovations (Speier and Venkatesh 2002). Thus, management support both directly promotes and reduces obstacles to utilization (H6b). As a result, we propose:

H6: Utilization is positively influenced by (a) user enablement and (b) management support.

\section{Utilization facilitates institutionalization, with both driving realized value}

Institutionalization reflects the degree to which the technology has become part of the standard work systems or "fabric" of the buying organization (Zmud and Apple 1992). It is seen by management as a platform for future growth, and warrants planned funding for future development (Meyer and Goes 1988). In their analysis of the diffusion of supermarket scanner equipment, Zmud and Apple (1992) confirm that the earlier a supermarket chain adopted the scanning technology, and the more extensive its intra-organizational diffusion (utilization), the greater the "routinization" and "infusion" of that technology within the organization. In their terminology, "routinization" refers to the degree to which the technology has become embedded in the standard work systems, while "infusion" refers to the degree to which work systems have evolved to exploit the capabilities of the technology. Both concepts are representative of the broader notion of institutionalization and supportive of the general idea that technology use and work system adaptation ("technology sensemaking") are iterative, mutually reinforcing processes that intensify over time, given appropriate management interventions (Jasperson et al. 2005). Consequently, higher levels of utilization and management support should each be associated with higher levels of institutionalization ( $\mathrm{H7a}, \mathrm{H} 7 \mathrm{~b})$. Therefore, we propose:

H7: Institutionalization is positively influenced by (a) utilization and (b) management support.

Davern and Kauffman (2000) draw an important distinction between a technology's potential value and its realized value, with the latter reflecting the net economic results achieved through the implementation of the technology. For buyers of technology products and related services, research suggests that a buyer's realized value perspectives may incorporate both service delivery-related factors (seller professionalism, schedule and budget performance, quality of deliverables, etc.) and "value in use" factors such as productivity gains or cost savings realized (Lapierre 1997). MIS and technology implementation literature point to multiple drivers of "value in use," conceptualized broadly as improved business performance. In the context of "volitional" information systems (Y. Malhotra and Galleta 2005), utilization and institutionalization are two of the most important. Utilization influences both the costs and benefits of a volitional system. From a cost perspective, an under-utilized IT system is an obvious management concern calling into question the worth of the technology investment. More positively, utilization is seen to support benefits through enhanced organizational performance. Goodhue and Thompson assert that the "technologyto-performance" chain requires both technology usage and "task technology fit" defined as "the degree to which a technology assists an individual in performing his or her portfolio of tasks" (1995, p. 216). In situations in which a particular technology "fits" or productively enables the work to be done, utilization of that technology will then yield positive results. For instance, Devaraj and Kohli (2003) track utilization of a decision support system providing clinical and financial information in a multi-hospital setting. Based on their analysis of system utilization over a 3 year period, they attribute improvements in mortality rates and financial metrics to the usage of system-provided information, thus supporting the idea that utilization and realized value are positively related (H8a).

Institutionalization also exerts significant influence on organizational performance effects of information systems. The degree to which work tasks and business processes have been altered to fit with or complement the new technology, represents an important determinant of improved performance and value (Hughes and Morton 2006). Joshi's (1990) analysis of successful versus failed materials management system implementations, identifies work system reorganization as a key distinguishing factor between the two. Findings on the role of "task-technology fit" in 
translating usage to performance are further evidence of the significance of institutionalization (Goodhue and Thompson 1995). The fit between IT systems and organization context in the case of ERP implementations has been found repeatedly to influence their organization-level performance (Ettlie et al. 2005; Ranganathan and Brown 2006). Across a diverse array of organizational technologies, usage and business process change are seen to work jointly in affecting productivity and overall organizational performance (Grover et al. 1998). Consequently, for most systems, higher levels of institutionalization should be associated with higher levels of realized value (H8b). Thus, we propose:

H8: Realized value is positively influenced by (a) utilization and (b) institutionalization.

\section{Assimilation success (reflected in realized value) positively influences relationship satisfaction}

The literature on customer value provides strong support for the idea that realized value influences relationship satisfaction. Customer value in the technology context is seen to arise from the integration efforts of the supply network involved in helping the organization fully assimilate a focal technology
(Matthyssens and Vandenbempt 2002). These multi-party efforts drive "value in use" (or realized value) for a customer, which reflect back on the service organizations assisting in that value creation. Given the empirical linkages recognized in the literature between Realized Value and relationship quality generally, and relationship satisfaction in particular (Ulaga and Eggert 2006a), the impact of realized value on relationship satisfaction should be significant (H9). Hence,

H9: Realized value has a direct positive influence on relationship satisfaction.

\section{Research model summary}

Taken collectively, these seller capabilities and buyer technology assimilation perspectives constitute both direct and indirect drivers of relationship satisfaction. The direct effects are consistent with the traditional role of a vendor, whereas the indirect effects portrayed in the assimilation sub-model showcase co-creation of value. While prior studies have tested the individual path relationships represented in the research model (summarized in Table 4), this study tests them in the context of a holistic model.

Table 4 Summary of main effects hypotheses

\begin{tabular}{|c|c|c|c|}
\hline Hypothesis & Antecedent & Consequence & Representative supporting literature \\
\hline H1a & Instrumental service $(+)$ & Relationship satisfaction & Schellhase et al. 1999, Ulaga and Eggert 2006b \\
\hline $\mathrm{H} 1 \mathrm{~b}$ & Interpersonal service $(+)$ & Relationship satisfaction & Abdul-Muhmin 2005; Bruhn and Frommeyer 2004 \\
\hline $\mathrm{H} 1 \mathrm{c}$ & Value Mindset (+) & Relationship satisfaction & Pardo 1997; Walter et al. 2003 \\
\hline $\mathrm{H} 2 \mathrm{a}$ & Instrumental service $(+)$ & Potential value & Menon et al. 2005; Ulaga and Eggert 2006b \\
\hline $\mathrm{H} 2 \mathrm{~b}$ & Interpersonal service $(+)$ & Potential value & Menon et al. 2005; Ulaga and Eggert 2006b \\
\hline $\mathrm{H} 2 \mathrm{c}$ & Value mindset $(+)$ & Potential value & Dawar and Vandenbosch 2004; Sengupta et al. 2000 \\
\hline $\mathrm{H} 2 \mathrm{~d}$ & Services scope $(+)$ & Potential value & Davern and Kauffman 2000 \\
\hline H3 & Potential value (+) & Management support & Kauffman and Popkowski-Leszczyc 2005 \\
\hline $\mathrm{H} 4 \mathrm{a}$ & Management support (+) & User enablement & Agarwal et al. 1997 \\
\hline H5a & Instrumental Service (+) & User enablement & Mathieson et al. 2001 \\
\hline $\mathrm{H} 5 \mathrm{~b}$ & Interpersonal Service (+) & User enablement & Mathieson et al. 2001 \\
\hline $\mathrm{H} 5 \mathrm{c}$ & Value mindset $(+)$ & User enablement & Mathieson et al. 2001 \\
\hline H5d & Services scope $(+)$ & User enablement & Mathieson et al. 2001 \\
\hline H6a & User enablement $(+)$ & Utilization & Mahmood and Swanberg 2001 \\
\hline H6b & Management support (+) & Utilization & Cooper and Bhattacherjee 2001; Igbaria et al. 1996 \\
\hline $\mathrm{H} 7 \mathrm{a}$ & Utilization $(+)$ & Institutionalization & Zmud and Apple 1992 \\
\hline $\mathrm{H} 7 \mathrm{~b}$ & Management Support (+) & Institutionalization & Higgins and Hogan 1999 \\
\hline $\mathrm{H} 8 \mathrm{a}$ & Utilization (+) & Realized value & Devaraj and Kohli 2003 \\
\hline $\mathrm{H} 8 \mathrm{~b}$ & Institutionalization $(+)$ & Realized Value & Ranganathan and Brown 2006 \\
\hline H9 & Realized value (+) & Relationship satisfaction & Ulaga and Eggert 2006a \\
\hline
\end{tabular}




\section{Appendix 3}

Table 5 Measurement model

\begin{tabular}{|c|c|c|c|c|c|c|c|c|c|c|}
\hline & Construct & $\begin{array}{l}\text { Item } \\
\text { codes }\end{array}$ & $\begin{array}{l}\text { Item - Total } \\
\text { correlation }^{\mathrm{a}}\end{array}$ & $\begin{array}{l}\text { Cronbach's } \\
\text { Alphab }^{\text {b }}\end{array}$ & $\begin{array}{l}\text { PLS outer } \\
\text { model } \\
\text { regression } \\
\text { weight }\end{array}$ & $\begin{array}{l}t \text {-value } \\
\text { (weight) }\end{array}$ & $\begin{array}{l}\text { PLS outer } \\
\text { model factor } \\
\text { loading }^{c}\end{array}$ & $\begin{array}{l}t \text {-value } \\
\text { (loading) }\end{array}$ & $\begin{array}{l}\text { Average } \\
\text { Variance } \\
\text { Extracted } \\
(A V E)^{d}\end{array}$ & $\begin{array}{l}\text { Composite } \\
\text { reliability }\end{array}$ \\
\hline \multirow{5}{*}{$\begin{array}{l}\text { Core operant } \\
\text { resource }\end{array}$} & \multicolumn{3}{|c|}{ Instrumental Service } & 0.85 & & & & & 0.693 & 0.900 \\
\hline & & PK34 & 0.634 & & 0.277 & 9.963 & 0.787 & 14.754 & & \\
\hline & & PK35 & 0.619 & & 0.284 & 8.601 & 0.778 & 10.311 & & \\
\hline & & PK36 & 0.830 & & 0.308 & 13.981 & 0.915 & 50.446 & & \\
\hline & & PK37 & 0.635 & & 0.331 & 12.212 & 0.843 & 22.875 & & \\
\hline \multirow{6}{*}{$\begin{array}{l}\text { Core operant } \\
\text { resource }\end{array}$} & \multicolumn{3}{|c|}{ Interpersonal Service } & 0.917 & & & & & 0.780 & 0.946 \\
\hline & & SO38R & 0.731 & & 0.159 & 7.244 & 0.798 & 16.858 & & \\
\hline & & SO39 & 0.837 & & 0.219 & 16.792 & 0.898 & 47.427 & & \\
\hline & & $\mathrm{SO} 40$ & 0.867 & & 0.239 & 14.438 & 0.928 & 69.157 & & \\
\hline & & SO41 & 0.876 & & 0.251 & 20.599 & 0.932 & 89.910 & & \\
\hline & & $\mathrm{SO} 42$ & 0.735 & & 0.259 & 14.418 & 0.852 & 24.129 & & \\
\hline \multirow{5}{*}{$\begin{array}{l}\text { Augmented } \\
\text { operant resource }\end{array}$} & \multicolumn{3}{|c|}{ Value Mindset } & 0.958 & & & & & 0.889 & 0.970 \\
\hline & & VM43 & 0.862 & & 0.253 & 29.130 & 0.920 & 43.009 & & \\
\hline & & VM44 & 0.902 & & 0.271 & 41.814 & 0.946 & 94.531 & & \\
\hline & & VM45 & 0.896 & & 0.271 & 34.590 & 0.942 & 86.085 & & \\
\hline & & VM46 & 0.931 & & 0.267 & 34.844 & 0.962 & 129.597 & & \\
\hline \multirow{27}{*}{$\begin{array}{l}\text { Augmented } \\
\text { operand resource }\end{array}$} & \multicolumn{10}{|c|}{ Services Scope (Formative) } \\
\hline & & $\mathrm{SS} 32 \mathrm{~A}$ & & & 0.502 & 2.470 & & & & \\
\hline & & SS32B & & & 0.878 & 5.782 & & & & \\
\hline & & $\mathrm{SS} 32 \mathrm{H}$ & & & 0.368 & 2.126 & & & & \\
\hline & \multicolumn{3}{|c|}{ Potential Value } & 0.916 & & & & & 0.756 & 0.939 \\
\hline & & PV1 & 0.807 & & 0.245 & 15.158 & 0.885 & 26.412 & & \\
\hline & & PV2 & 0.826 & & 0.230 & 15.471 & 0.893 & 28.696 & & \\
\hline & & PV3 & 0.840 & & 0.214 & 16.149 & 0.897 & 31.743 & & \\
\hline & & PV4 & 0.793 & & 0.212 & 14.943 & 0.864 & 22.449 & & \\
\hline & & PV5 & 0.682 & & 0.252 & 8.877 & 0.804 & 14.798 & & \\
\hline & \multicolumn{3}{|c|}{ Management Support } & 0.944 & & & & & 0.902 & 0.965 \\
\hline & & MS6 & 0.875 & & 0.359 & 27.942 & 0.948 & 95.461 & & \\
\hline & & MS7 & 0.923 & & 0.367 & 36.876 & 0.969 & 174.690 & & \\
\hline & & MS8 & 0.860 & & 0.326 & 25.492 & 0.933 & 63.202 & & \\
\hline & \multicolumn{3}{|c|}{ User Enablement } & 0.915 & & & & & 0.797 & 0.940 \\
\hline & & UE12 & 0.827 & & 0.318 & 17.279 & 0.916 & 57.501 & & \\
\hline & & UE13 & 0.832 & & 0.286 & 15.180 & 0.914 & 43.217 & & \\
\hline & & UE14 & 0.828 & & 0.270 & 21.902 & 0.902 & 33.016 & & \\
\hline & & UE15 & 0.736 & & 0.244 & 12.406 & 0.838 & 21.218 & & \\
\hline & \multicolumn{3}{|l|}{ Utilization } & 0.883 & & & & & 0.896 & 0.945 \\
\hline & & UT16 & 0.794 & & 0.483 & 24.752 & 0.937 & 68.126 & & \\
\hline & & UT17 & 0.794 & & 0.573 & 28.220 & 0.956 & 100.968 & & \\
\hline & \multicolumn{3}{|c|}{ Institutionalization } & 0.792 & & & & & 0.829 & 0.906 \\
\hline & & IN23 & 0.658 & & 0.535 & 20.725 & 0.905 & 36.298 & & \\
\hline & & IN24 & 0.658 & & 0.564 & 20.050 & 0.915 & 42.870 & & \\
\hline & \multicolumn{3}{|c|}{ Realized Value } & 0.948 & & & & & 0.814 & 0.963 \\
\hline & & IN25 & 0.867 & & 0.195 & 24.370 & 0.917 & 62.270 & & \\
\hline
\end{tabular}


Table 5 (continued)

\begin{tabular}{|c|c|c|c|c|c|c|c|c|c|}
\hline Construct & $\begin{array}{l}\text { Item } \\
\text { codes }\end{array}$ & $\begin{array}{l}\text { Item - Total } \\
\text { correlation }^{\text {a }}\end{array}$ & $\begin{array}{l}\text { Cronbach's } \\
\text { Alpha }^{\text {b }}\end{array}$ & $\begin{array}{l}\text { PLS outer } \\
\text { model } \\
\text { regression } \\
\text { weight }\end{array}$ & $\begin{array}{l}t \text {-value } \\
\text { (weight) }\end{array}$ & $\begin{array}{l}\text { PLS outer } \\
\text { model factor } \\
\text { loading }^{\mathrm{c}}\end{array}$ & $\begin{array}{l}t \text {-value } \\
\text { (loading) }\end{array}$ & $\begin{array}{l}\text { Average } \\
\text { Variance } \\
\text { Extracted } \\
(A V E)^{d}\end{array}$ & $\begin{array}{l}\text { Composite } \\
\text { reliability }\end{array}$ \\
\hline & IN26 & 0.872 & & 0.202 & 25.270 & 0.924 & 65.683 & & \\
\hline & IN27 & 0.880 & & 0.186 & 29.212 & 0.929 & 62.869 & & \\
\hline & RV28 & 0.919 & & 0.186 & 37.389 & 0.947 & 75.385 & & \\
\hline & RV29 & 0.912 & & 0.194 & 29.180 & 0.946 & 86.445 & & \\
\hline & RV30R & 0.657 & & 0.140 & 10.852 & 0.732 & 12.232 & & \\
\hline \multicolumn{2}{|c|}{ Relationship Satisfaction } & & 0.963 & & & & & 0.901 & 0.973 \\
\hline & RS47 & 0.907 & & 0.271 & 53.194 & 0.949 & 100.084 & & \\
\hline & RS48 & 0.890 & & 0.262 & 54.642 & 0.938 & 72.315 & & \\
\hline & RS49 & 0.899 & & 0.256 & 48.388 & 0.943 & 77.270 & & \\
\hline & RS50 & 0.939 & & 0.264 & 62.940 & 0.967 & 164.064 & & \\
\hline
\end{tabular}

Threshold values are: ${ }^{\mathrm{a}}$ ITC $>0.5$ (Hair et al. 1998, p. 118), ${ }^{\mathrm{b}} \alpha>0.7$ (Hair et al. 1998, p. 118), ${ }^{\mathrm{c}} \lambda>0.707$ (Barclay et al. 1995, p. 295), ${ }^{\mathrm{d}}$ AVE $>0.5$ (Chin 1998b, p. 321), ${ }^{\text {e }} \rho_{\mathrm{c}}>0.7$ (Barclay et al. 1995, p. 297)

Open Access This article is distributed under the terms of the Creative Commons Attribution 4.0 International License (http:// creativecommons.org/licenses/by/4.0/), which permits unrestricted use, distribution, and reproduction in any medium, provided you give appropriate credit to the original author(s) and the source, provide a link to the Creative Commons license, and indicate if changes were made.

\section{References}

Abdul-Muhmin, A. G. (2005). Instrumental and interpersonal determinants of relationship satisfaction and commitment in industrial markets. Journal of Business Research, 58(5), 619-628.

Abratt, R., \& Kelly, P. M. (2002). Customer-supplier partnerships: perceptions of a successful key account management program. Industrial Marketing Management, 31(5), 467-476.

Adamson, B., Dixon, M., \& Toman, N. (2012). The end of solution sales. Harvard Business Review, 90(7/8), 60-68.

Adamson, B., Dixon, M., \& Toman, N. (2013). Dismantling the sales machine. Harvard Business Review, 91(11), 102-109.

Agarwal, R., Tanniru, M., \& Wilemon, D. (1997). Assimilating information technology innovations: strategies and moderating influences. IEEE Transactions on Engineering Management, 44(4), 347-358.

Alexander, J. A., \& Hordes, M. W. (2003). S-Business: reinventing the services organization. New York: SelectBooks, Inc.

Anakwe, U. P., Igbaria, M., \& Anandarajan, M. (2000). Management practices across cultures: role of support in technology use. Journal of International Business Studies, 31(4), 653-666.

Anderson, R. E. (1973). Consumer dissatisfaction: the effect of disconfirmed expectancy on perceived product performance. Journal of Marketing Research, 10(1), 38-44.

Anderson, J. C. (1995). Relationships in business markets: exchange episodes, value creation, and their empirical assessment. Journal of the Academy of Marketing Science, 23(4), 346-350.

Anderson, J. C., \& Narus, J. A. (1998). Business marketing: understand what customers value. Harvard Business Review, 76(6), 53-65.
Arnould, E. (2005). Animating the big middle. Journal of Retailing, 81(2), 89-96.

Baines, T., \& Lightfoot, H. (2013). Made to serve: how manufacturers can compete through servitization and product-service systems. West Sussex: Wiley.

Barnes, J. G., \& McTavish, R. (1983). Segmenting industrial markets by buyer sophistication. European Journal of Marketing, 17(6), 16-33.

Baron, R.M. \& Kenny, D.A. (1986). The moderator-mediator variable distinction in social psychological research: conceptual, strategic and statistical considerations. Journal of Personality and Social Psychology, 51(6), 1173-1182.

Bergkvist, L., \& Rossiter, J. R. (2007). The predictive validity of multiple-item versus single-item measures of the same constructs. Journal of Marketing Research, 44(2), 175-184.

Bolton, R. N., Smith, A. K., \& Wagner, J. (2003). Striking the right balance: designing service to enhance business-to-business relationships. Journal of Service Research, 5(4), 271-291.

Bruhn, M., \& Frommeyer, A. (2004). Development of relationship marketing constructs over time: antecedents and consequences of customer satisfaction in a business-to-business environment. Journal of Relationship Marketing, 3(4), 61-76.

Burton-Jones, A., \& Straub, D. W. (2006). Reconceptualizing system usage: an approach and empirical test. Information Systems Research, 17(3), 228-246.

Chin, W. W. (1998a). Issues and opinion on structural equation modeling. MIS Quarterly, 22(1), vii-xvi.

Chin, W. W. (1998b). The partial least squares approach to structural equation modeling. In G. A. Marcoulides (Ed.), Modern methods for business research (pp. 295-336). Mahwah: Lawrence Erlbaum Associates.

Chin, W. W., \& Todd, P. A. (1995). On the use, usefulness and ease of use of structural equation modeling in MIS research: A note of caution. MIS Quarterly, 19(2), 237-246.

Chircu, A. M., \& Kauffman, R. J. (2000). Limits to value in electronic commerce-related IT investments. Journal of Management Information Systems, 17(2), 59-80.

Chumpitaz, R. \& Paparoidamis, N.G. (2004). Service quality and marketing performance in business-to-business markets: exploring the 
mediating role of client satisfaction. Managing Service Quality, 14(2/3), 235--248.

Cooper, R. B., \& Bhattacherjee, A. (2001). Preliminary evidence for the effect of automatic responses to authority on information technology diffusion. Database for Advances in Information Systems, 32(3), $36-50$.

Creswell, J. W. (2003). Research design: quantitative, qualitative, and mixed methods approaches (2nd ed.). Thousand Oaks: Sage Publications.

Cronbach, L. J. (1987). Statistical tests for moderator variables: flaws in analyses recently proposed. Psychological Bulletin, 102(3), 414 417.

Cusumano, M. A. (2003). Finding your balance in the products and services debate. Communications of the ACM, 46(3), 15-17.

Davern, M. J., \& Kauffman, R. J. (2000). Discovering potential and realizing value from information technology investments. Journal of Management Information Systems, 16(4), 121-143.

Davies, A., Brady, T., \& Hobday, M. (2006). Charting a path toward integrated solutions. MIT Sloan Management Review, 47(3), 39-48.

Dawar, N., \& Vandenbosch, M. B. (2004). The seller's hidden advantage. MIT Sloan Management Review, 45(2), 83-88.

Devaraj, S., \& Kohli, R. (2003). Performance impacts of information technology: is actual usage the missing link? Management Science, 49(3), 273-289.

Diamantopoulos, A., Sarstedt, M., Fuchs, C., Wilczynski, P., \& Kaiser, S. (2012). Guidelines for choosing between multi-item and single-item scales for construct measurement: a predictive validity perspective. Journal of the Academy of Marketing Science, 40(3), 434-449.

Easingwood, C., Moxey, S., \& Capleton, H. (2006). Bringing high technology to market: successful strategies employed in the worldwide software industry. Journal of Product Innovation Management, 23(6), 498-511.

Eggert, A., \& Ulaga, W. (2002). Customer perceived value: a substitute for satisfaction in business markets? Journal of Business \& Industrial Marketing, 17(2/3), 107-118.

Eggert, A., Ulaga, W., \& Schultz, F. (2006). Value creation in the relationship life cycle: a quasi-longitudinal analysis. Industrial Marketing Management, 35(1), 20-27.

Ettlie, J. E., Perotti, V. J., Joseph, D. A., \& Cotteleer, M. J. (2005). Strategic predictors of successful enterprise system deployment. International Journal of Operations \& Production Management, 25(9/10), 953-972.

Evans, K. R., McFarland, R. G., Dietz, B., \& Jaramillo, F. (2012). Advancing sales performance research: a focus on five underresearched topic areas. Journal of Personal Selling \& Sales Management, 32(1), 89-106.

Fang, E., Palmatier, R. W., \& Steenkamp, J.-B. E. M. (2008). Effect of service transition strategies on firm value. [Article]. Journal of Marketing, 72(5), 1-14.

Fichman, R. G. (2000). The diffusion and assimilation of information technology innovations. In R. W. Zmud (Ed.), Framing the domains of IT Management: Projecting the future through the past (pp. 105127). Cincinnati: Pinnaflex Educational Resources, Inc.

Fichman, R. G., \& Kemerer, C. F. (1997). The assimilation of software process innovations: an organizational learning perspective. Management Science, 43(10), 1345-1363.

Fornell, C., \& Larcker, D. F. (1981). Evaluating structural equation models with unobservable variables and measurement error. Journal of Marketing Research, 18(1), 39-50.

Frank, K. A., Zhao, Y., \& Borman, K. (2004). Social capital and the diffusion of innovations within organizations: the case of computer technology in schools. Sociology of Education, 77(2), 148-171.

Gebauer, H., \& Friedli, T. (2005). Behavioral implications of the transition process from products to services. Journal of Business \& Industrial Marketing, 20(2/3), 70-78.
Georges, L., \& Eggert, A. (2003). Key account managers' role within the value creation process of collaborative relationships. Journal of Business to Business Marketing, 10(4), 1-22.

Goodhue, D. L., \& Thompson, R. L. (1995). Task-technology fit and individual performance. MIS Quarterly, 19(2), 213-236.

Gordon, R., \& Lovelock, J. (2014). Global IT spending on pace to grow 2.1 percent in 2014. Forbes. Retrieved from http://www.forbes.com/ sites/gartnergroup/2014/07/02/global-it-spending-on-pace-to-grow2-1-percent-in-2014/

Green, R. F., Zimmerer, T. W., \& Steadman, M. E. (1994). The role of buyer sophistication in competitive bidding. Journal of Business \& Industrial Marketing, 9(1), 51-59.

Gronroos, C. (1984). A service quality model and its marketing implications. European Journal of Marketing, 18(4), 36- 44.

Gronroos, C. (1990). Service management and marketing: managing the moments of truth in service competition. Lexington: Lexington Books.

Grover, V., Teng, J., Segars, A. H., \& Fiedler, K. (1998). The influence of information technology diffusion and business process change on perceived productivity: the IS executive's perspective. Information \& Management, 34(3), 141-159.

Hair, J., Andersen, R.E., Tatham, R.L., \& Black, W.C. (1998). Multivariate data analysis (5th ed.). Upper Saddle River, NJ: Prentice-Hall, Inc.

Hair, J., Ringle, C., \& Sarstedt, M. (2011). PLS-SEM: indeed a silver bullet. Journal of Marketing Theory and Practice, 19(2), 139-151.

Hair, J., Sarstedt, M., Ringle, C., \& Mena, J. (2012). An assessment of the use of partial least squares structural equation modeling in marketing research. Journal of the Academy of Marketing Science, 40(3), 414 433.

Hausman, A. (2001). Variations in relationship strength and its impact on performance and satisfaction in business relationships. Journal of Business \& Industrial Marketing, 16(6/7), 600-616.

Heide, J. B., \& John, G. (1992). Do norms matter in marketing relationships? Journal of Marketing, 56(2), 32-44.

Helander, A., \& Moller, K. (2008). How to become solution provider: system supplier's strategic tools. Journal of Business-to-Business Marketing, 15(3), 247-287.

Herrmann, A., Gassmann, O., \& Eisert, U. (2007). An empirical study of the antecedents for radical product innovations and capabilities for transformation. Journal of Engineering and Technology Management, 24, 92-120.

Higgins, S. H., \& Hogan, P. T. (1999). Internal diffusion of high technology industrial innovations: an empirical study. Journal of Business \& Industrial Marketing, 14(1), 61-75.

Hoch, D. J., Roeding, C. R., Purkert, G., \& Lindner, S. K. (2000). Secrets of software success: management insights from 100 software firms around the world. Boston: Harvard Business School Press.

Homburg, C. (1998). On closeness to the customer in industrial markets. Journal of Business to Business Marketing, 4(4), 35-72.

Homburg, C., \& Rudolph, B. (2001). Customer satisfaction in industrial markets: dimensional and multiple role issues. Journal of Business Research, 52(1), 15-33.

Homburg, C., Hoyer, W. D., \& Fassnacht, M. (2002). Service orientation of a retailer's business strategy: dimensions, antecedents, and performance outcomes. Journal of Marketing, 66(4), 86-101.

Homburg, C., Fassnacht, M., \& Guenther, C. (2003). The role of soft factors in implementing a service-oriented strategy in industrial marketing companies. Journal of Business to Business Marketing, 10(2), 23-51.

Homburg, C., Kuester, S., Beutin, N., \& Menon, A. (2005). Determinants of customer benefits in business-to-business markets: a crosscultural comparison. Journal of International Marketing, 13(3), 131.

Huang, M., \& Rust, R. T. (2014). Should your business be less productive? MIT Sloan Management Review, 55(3), 67-72. 
Hughes, A., \& Morton, M. S. S. (2006). The transforming power of complementary assets. MIT Sloan Management Review, 47(4), 5058.

Igbaria, M., Parasuraman, S., \& Baroudi, J. J. (1996). A motivational model of microcomputer usage. Journal of Management Information Systems, 13(1), 127-143.

Igbaria, M., Zinatelli, N., Cragg, P., \& Cavaye, A. L. M. (1997). Personal computing acceptance factors in small firms: a structural equation model. MIS Quarterly, 21(3), 279-305.

Iyer, G., Ravindran, S., \& Reckers, P. M. J. (2006). Procurement of IT consulting services and firm-specific characteristics. Journal of the Association for Information Systems, 7(4), 207-240.

Jasperson, J., Carter, P. E., \& Zmud, R. W. (2005). A comprehensive conceptualization of post-adoptive behaviors associated with information technology work systems. MIS Quarterly, 29(3), 525-557.

Joshi, K. (1990). Reorganization of the work system for successful information systems implementation: a case study. Information \& Management, 19(4), 271-284.

Kauffman, R. G., \& Popkowski-Leszczyc, P. T. L. (2005). An optimization approach to business buyer choice sets: how many suppliers should be included? Industrial Marketing Management, 34(1), 3 12.

Kauffman, R. J., \& Tsai, J. Y. (2009). The unified procurement strategy for enterprise software: a test of the "move to the middle" hypothesis. Journal of Management Information Systems, 26(2), 177-204.

Keil, M., \& Mähring, M. (2010). Is your project turning into a black hole? California Management Review, 53(1), 6-31.

Kumar, P. (2002). The impact of performance, cost, and competitive considerations on the relationship between satisfaction and repurchase intent in business markets. Journal of Service Research, 5(1), $55-68$.

Kwon, T. H., \& Zmud, R. W. (1987). Unifying the fragmented models of information systems implementation. In R. J. Boland \& R. A. Hirschheim (Eds.), Critical issues in information systems research (pp. 227-251). New York: Wiley.

Lai, F., Li, X., \& Lai, V. S. (2013). Transaction-specific investments, relational norms, and ERP customer satisfaction: a mediation analysis. Decision Sciences, 44(4), 679-711.

Lam, S. Y., Shankar, V., Erramilli, M. K., \& Murthy, B. (2004). Customer value, satisfaction, loyalty, and switching costs: an illustration from a business-to-business service context. Journal of the Academy of Marketing Science, 32(3), 293-311.

Lapierre, J. (1997). What does value mean in business-to-business professional services? International Journal of Service Industry Management, 8(5), 377-397.

Lapierre, J. (2000). Customer-perceived value in industrial contexts. Journal of Business \& Industrial Marketing, 15(2/3), 122-140.

Levitt, T. (1980). Marketing success through differentiation - of anything. Harvard Business Review, 58(1), 83-91.

Liang, H., Saraf, N., Hu, Q., \& Xue, Y. (2007). Assimilation of enterprise systems: the effect of institutional pressures and the mediating role of top management. MIS Quarterly, 31(1), 59-87.

Lusch, R. F., Vargo, S. L., \& Tanniru, M. (2010). Service, value networks and learning. Journal of the Academy of Marketing Science, 38(1), 19-31.

Lytle, R. S., Hom, P. W., \& Mokwa, M. P. (1998). SERV*OR: a managerial measure of organizational service-orientation. Journal of Retailing, 74(4), 455-489.

MacCormack, A. (2003). The true costs of software. Computerworld, 37, 44.

Macintosh, G. (2007). Customer orientation, relationship quality, and relational benefits to the firm. Journal of Services Marketing, 21(3), 150-157.

Madhavaram, S., \& Hunt, S. D. (2008). The service-dominant logic and a hierarchy of operant resources: developing masterful operant resources and implications for marketing strategy. Journal of the Academy of Marketing Science, 36(1), 67-82.

Mahmood, M. A., \& Swanberg, D. L. (2001). Factors affecting information technology usage: a meta-analysis of the empirical literature. Journal of Organizational Computing and Electronic Commerce, 11(2), 107-130.

Malhotra, Y., \& Galleta, D. (2005). A multidimensional commitment model of volitional systems adoption and usage behavior. Journal of Management Information Systems, 22(1), 117-151.

Malhotra, N. K., Kim, S. S., \& Patil, A. (2006). Common method variance in IS research: a comparison of alternative approaches and a reanalysis of past research. Management Science, 52(12), 18651883.

Mathieson, K., Peacock, E., \& Chin, W. W. (2001). Extending the technology acceptance model: the influence of perceived user resources. DATA BASE for Advances in Information Systems, 32(3), 86-112.

Matthyssens, P., \& Vandenbempt, K. (2002, May). Towards a model of value addition and value innovation efforts in industrial models. Paper presented at the 18th Annual Industrial Marketing and Purchasing (IMP) Group Conference, Dijon, France.

Melville, N., Kraemer, K. L., \& Gurbaxani, V. (2004). Information technology and organizational performance: an integrative model of. IT business value MIS Quarterly, 28(2), 283-322.

Menon, A., Homburg, C., \& Beutin, N. (2005). Understanding customer value in business-to-business relationships. Journal of Business to Business Marketing, 12(2), 1-38.

Meyer, A. D., \& Goes, J. B. (1988). Organizational assimilation of innovations: a multilevel contextual analysis. Academy of Management Journal, 31(4), 897-923.

Michel, S., Brown, S. W., \& Gallan, A. S. (2008). An expanded and strategic view of discontinuous innovations: deploying a servicedominant logic. Journal of the Academy of Marketing Science, 36(1), 54-66.

Mohr, J. J., \& Sengupta, S. (2002). Managing the paradox of inter-firm learning: the role of governance mechanisms. Journal of Business \& Industrial Marketing, 17(4), 282-301.

Mohr, J. J., Sengupta, S., \& Slater, S. (2005). Marketing of hightechnology products and innovations (2nd ed.). Upper Saddle River: Pearson Prentice Hall.

Neu, W. A., \& Brown, S. W. (2005). Forming successful business-tobusiness services in goods-dominant firms. Journal of Service Research, 8(1), 3-17.

Ngo, L. V., \& O'Cass, A. (2009). Creating value offerings via operant resource-based capabilities. Industrial Marketing Management, $38(1), 45-59$.

Oliva, R., Gebauer, H., \& Brann, J. M. (2012). Separate or integrate? Assessing the impact of separation between product and service business on service performance in product manufacturing firms. Journal of Business-to-Business Marketing, 19(4), 309-334.

Oliver, R. L. (1980). A cognitive model of the antecedents and consequences of satisfaction decisions. Journal of Marketing Research, $17(4), 460-469$.

Oliver, R. L. (1997). Satisfaction: a behavioral perspective on the consumer. Boston: Irwin McGraw-Hill.

Parasuraman, A., Zeithaml, V. A., \& Berry, L. L. (1985). A conceptual model of service quality and its implications for future research. Journal of Marketing, 49(4), 41-50.

Parasuraman, A., Zeithaml, V. A., \& Berry, L. L. (1988). SERVQUAL: a multiple-item scale for measuring consumer perceptions of service quality. Journal of Retailing, 64(1), 12-40.

Pardo, C. (1997). Key account management in the business to business field: the key account's point of view. Journal of Personal Selling \& Sales Management, 17(4), 17-26.

Patterson, P. G., Johnson, L. W., \& Spreng, R. A. (1997). Modeling the determinants of customer satisfaction for business-to-business 
professional services. Journal of the Academy of Marketing Science, 25(1), 4-17.

Podsakoff, P. M., \& Organ, D. W. (1986). Self-reports in organizational research: problems and prospects. Journal of Management, 12(4), 531-544.

Rai, A., Pavlou, P. A., Im, G., \& Du, S. (2012). Interfirm IT capability profiles and communications for cocreating relational value: evidence from the logistics industry. MIS Quarterly, 36(1), 233-A5.

Ramani, G., \& Kumar, V. (2008). Interaction orientation and firm performance. Journal of Marketing, 72(1), 27-45.

Ranganathan, C., \& Brown, C. V. (2006). ERP Investments and the market value of firms: toward an understanding of influential ERP project variables. Information Systems Research, 17(2), 145-161.

Rosenbaum, M. S., Massiah, C., \& Jackson, D. W., Jr. (2006). An investigation of trust, satisfaction, and commitment on repurchase intentions in professional services. Services Marketing Quarterly, 27(3), $115-135$.

Rust, R. T., \& Huang, M. (2012). Optimizing service productivity. Journal of Marketing, 76(2), 47-66.

Rust, R. T., \& Oliver, R. L. (2000). Should we delight the customer? Journal of the Academy of Marketing Science, 28(1), 86-94.

Samli, A. C., Jacobs, L. W., \& Wills, J. (1992). What presale and postsale services do you need to be competitive. Industrial Marketing Management, 21(1), 33-41.

Sawhney, M. S., Balasubramanian, S., \& Krishnan, V. V. (2004). Creating growth with services. MIT Sloan Management Review, 45(2), 34 43.

Schellhase, R., Hardock, P., \& Ohlwein, M. (1999). Customer satisfaction in business-to-business marketing: the case of retail organizations and their suppliers. Journal of Business \& Industrial Marketing, 14(5/6), 416-432.

Sengupta, S., Krapfel, R. E., \& Pusateri, M. A. (2000). An empirical investigation of key account salesperson effectiveness. Journal of Personal Selling \& Sales Management, 20(4), 253-261.

Shankar, V., Berry, L. L., \& Dotzel, T. (2009). A practical guide to combining products + services. Harvard Business Review, 87(11), 94 99.

Shih, C.-F., \& Venkatesh, A. (2004). Beyond adoption: development and application of a use-diffusion model. Journal of Marketing, 68(1), 59-72.

Simon, S. J., Grover, V., Teng, J. T. C., \& Whitcomb, K. (1996). The relationship of information system training methods and cognitive ability to end-user satisfaction, comprehension, and skill transfer: a longitudinal field study. Information Systems Research, 7(4), 466490.

Slater, S. F., \& Narver, J. C. (1994). Market orientation, customer value, and superior performance. Business Horizons, 37(2), 22-28.

Son, J.-Y., \& Benbasat, I. (2007). Organizational buyers' adoption and use of B2B electronic marketplaces: efficiency- and legitimacyoriented perspectives. Journal of Management Information Systems, 24(1), 55-99.

Spector, P. E. (2006). Method variance in organizational research: truth or urban legend? Organizational Research Methods, 9(2), 221-232.
Speier, C., \& Venkatesh, V. (2002). The hidden minefields in the adoption of sales force automation technologies. Journal of Marketing, 66(3), 98-111.

Srite, M., \& Karahanna, E. (2006). The role of espoused national cultural values in technology acceptance. MIS Quarterly, 30(3), 679-704.

Swaminathan, V., \& Moorman, C. (2009). Marketing alliances, firm networks, and firm value creation. Journal of Marketing, 73(5), 52-69.

Tuli, K. R., Kohli, A. K., \& Bharadwaj, S. G. (2007). Rethinking customer solutions: from product bundles to relational processes. Journal of Marketing, 71(3), 1-17.

Ulaga, W., \& Eggert, A. (2006a). Relationship value and relationship quality: broadening the nomological network of business-tobusiness relationships. European Journal of Marketing, 40(3/4), 311-327.

Ulaga, W., \& Eggert, A. (2006b). Value-based differentiation in business relationships: gaining and sustaining key supplier status. Journal of Marketing, 70(1), 119-136.

Ulaga, W., \& Reinartz, W. J. (2011). Hybrid offerings: how manufacturing firms combine goods and services successfully. Journal of Marketing, 75(6), 5-23.

Urban, G. L., \& Hauser, J. R. (1993). Design and marketing of new products (2nd ed.). Upper Saddle River: Prentice-Hall, Inc.

Van Bruggen, G. H., Lilien, G. L., \& Kacker, M. (2002). Informants in organizational marketing research: why use multiple informants and how to aggregate responses. Journal of Marketing Research, 39(4), 469-478.

Vandenbosch, M. B., \& Dawar, N. (2002). Beyond better products: capturing value in customer interactions. MIT Sloan Management Review, 43(4), 35-42.

Vargo, S. L., \& Lusch, R. F. (2004). Evolving to a new dominant logic for marketing. Journal of Marketing, 68(1), 1-17.

Vargo, S. L., \& Lusch, R. F. (2008a). From goods to service(s): divergences and convergences of logics. Industrial Marketing Management, 37(3), 254-259.

Vargo, S. L., \& Lusch, R. F. (2008b). Service-dominant logic: continuing the evolution. Journal of the Academy of Marketing Science, 36(1), $1-10$.

Vargo, S. L., \& Lusch, R. F. (2008c). Why "service"? Journal of the Academy of Marketing Science, 36(1), 25-38.

Walter, A., Muller, T. A., Helfert, G., \& Ritter, T. (2003). Functions of industrial supplier relationships and their impact on relationship quality. Industrial Marketing Management, 32(2), 159-169.

Wen, H. J., \& Shih, S. C. (2006). Strategic information technology prioritization. Journal of Computer Information Systems, 46(4), 54-63.

Wixom, B. H., \& Watson, H. J. (2001). An empirical investigation of the factors affecting data warehousing success. MIS Quarterly, 25(1), $17-41$.

Woodside, A. G. (1996). Theory of rejecting superior, new technologies. Journal of Business \& Industrial Marketing, 11(3/4), 25-43.

Young, L. (2008). From products to services. West Sussex: Wiley.

Zmud, R. W., \& Apple, L. E. (1992). Measuring technology incorporation / infusion. Journal of Product Innovation Management, 9(2), $148-155$. 